Article

\title{
Surprising Drought Tolerance of Fir (Abies) Species between Past Climatic Adaptation and Future Projections Reveals New Chances for Adaptive Forest Management
}

\author{
Csaba Mátyás 1,* , František Beran ${ }^{2}$, Jaroslav Dostál ${ }^{2}$, Jiří Čáp ${ }^{2}$, Martin Fulín 2, Monika Vejpustková ${ }^{3}$, Gregor Božič ${ }^{4}$, \\ Pál Balázs ${ }^{1}$ and Josef Frýdl ${ }^{2, *}$ \\ 1 Institute of Environmental and Earth Sciences, Faculty of Forestry, University of Sopron, \\ 9400 Sopron, Hungary; balazs.pal@uni-sopron.hu \\ 2 Department of Biology and Forest Tree Breeding, Forestry and Game Management Research Institute, \\ 25202 Jíloviště, Czech Republic; beran@vulhm.cz (F.B.); dostal@vulhm.cz (J.D.); cap@vulhm.cz (J.Č.); \\ fulin@vulhm.cz (M.F.) \\ 3 Department of Forest Ecology, Forestry and Game Management Research Institute, \\ 25202 Jíloviště, Czech Republic; vejpustkova@vulhm.cz \\ 4 Department of Forest Physiology and Genetics, Slovenian Forestry Institute, 1000 Ljubljana, Slovenia; \\ gregor.bozic@gozdis.si \\ * Correspondence: matyas.csaba@uni-sopron.hu (C.M.); frydl@vulhm.cz (J.F.)
}

Citation: Mátyás, C.; Beran, F.; Dostál, J.; Čáp, J.; Fulín, M.; Vejpustková, M.; Božič, G.; Balázs, P.; Frýdl, J. Surprising Drought Tolerance of Fir (Abies) Species between Past Climatic Adaptation and Future Projections Reveals New Chances for Adaptive Forest Management. Forests 2021, 12, 821. https://doi.org/10.3390/f12070821

Academic Editor: Maciej Pach

Received: 11 May 2021

Accepted: 14 June 2021

Published: 22 June 2021

Publisher's Note: MDPI stays neutral with regard to jurisdictional claims in published maps and institutional affiliations.

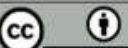

Copyright: () 2021 by the authors. Licensee MDPI, Basel, Switzerland. This article is an open access article distributed under the terms and conditions of the Creative Commons Attribution (CC BY) license (http://creativecommons.org/licenses /by/4.0/).

\begin{abstract}
Research Highlights: Data of advanced-age provenance tests were reanalyzed applying a new approach, to directly estimate the growth of populations at their original sites under individually generated future climates. The results revealed the high resilience potential of fir species. Background and Objectives: The growth and survival of silver fir under future climatic scenarios are insufficiently investigated at the xeric limits. The selective signature of past climate determining the current and projected growth was investigated to analyze the prospects of adaptive silviculture and assisted transfer of silver fir populations, and the introduction of nonautochthonous species. Materials and Methods: Hargreaves' climatic moisture deficit was selected to model height responses of adult populations. Climatic transfer distance was used to assess the relative drought stress of populations at the test site, relating these to the past conditions to which the populations had adapted. ClimateEU and ClimateWNA pathway RCP8.5 data served to determine individually past, current, and future moisture deficit conditions. Besides silver fir, other fir species from South Europe and the American Northwest were also tested. Results: Drought tolerance profiles explained the responses of transferred provenances and predicted their future performance and survival. Silver fir displayed significant within-species differentiation regarding drought stress response. Applying the assumed drought tolerance limit of $100 \mathrm{~mm}$ relative moisture deficit, most of the tested silver fir populations seem to survive their projected climate at their origin until the end of the century. Survival is likely also for transferred Balkan fir species and for grand fir populations, but not for the Mediterranean species. Conclusions: The projections are less dramatic than provided by usual inventory assessments, considering also the resilience of populations. The method fills the existing gap between experimentally determined adaptive response and the predictions needed for management decisions. It also underscores the unique potential of provenance tests.
\end{abstract}

Keywords: climate change; common garden; provenance test; silver fir; grand fir; Balkan firs; drought stress; resilience; climate transfer distance; adaptation

\section{Introduction}

The rapid change of climatic conditions, which is unprecedented on the scale of the Holocene, across all forest zones, is the greatest challenge to the long-term stability of 
forest ecosystems and contemporary forest management [1]. The large-scale shift in forest site conditions challenges the ecosystems along with the rear/xeric limits especially $[2,3]$. Climatic analyses list subcontinental East-Central Europe among future global climatic hotspots [4]. Compared to the 1981-2010 reference period, climate projections indicate that air temperature e.g., in the Czech Republic will continue to rise by an average of about $1{ }^{\circ} \mathrm{C}$ over the next 30 years. Differences between the emission scenarios will increase after 2050. Compared to the reference period, the annual mean temperature will increase by 2.0 ${ }^{\circ} \mathrm{C}$ (RCP4.5, - RCP: Representative Concentration Pathway is the greenhouse gas concentration trajectory assumed for various climate change scenarios), respectively, and by more than $4.0^{\circ} \mathrm{C}$ (RCP8.5) until the end of the century. In extensive lowlands, such as in Hungary, more than half of the years may be extremely dry in the last quarter of the present century [5,6]. Less precipitation and higher temperatures in summer threaten the stability of forest ecosystems (Figure 1). Droughts lead to growth decline and mortality, particularly among conifers such as silver fir [7,8], and affect the genetic diversity of forest tree populations $[9,10]$.

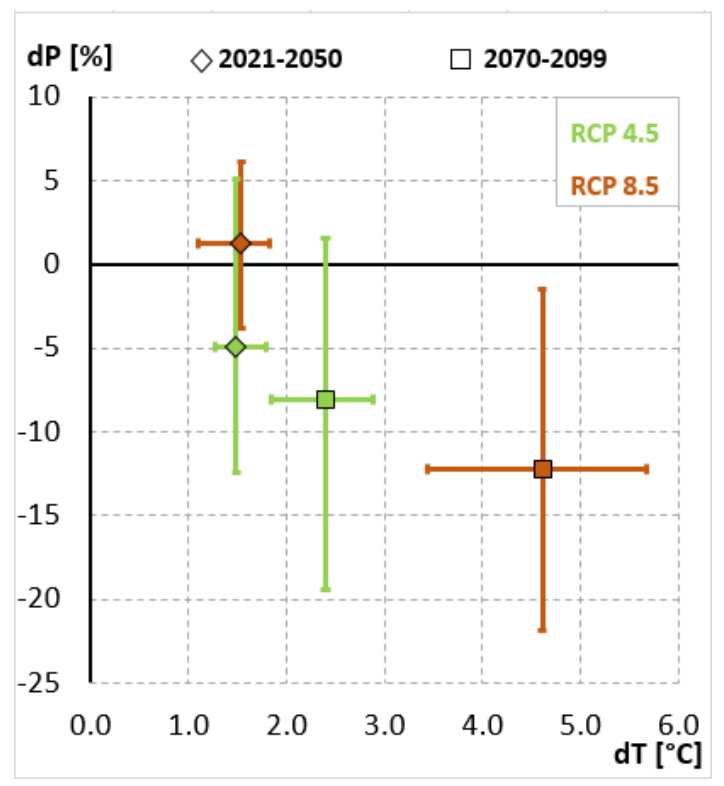

Figure 1. Expected change of temperature $(d T)$ and precipitation $(d P)$ in the summer quarter (June-July-August) in southwest Hungary at the xeric limits of silver fir based on the RCP4.5 and RCP8.5 scenarios. Reference: mean of 1971 to 2000. Dots: ensemble means (10 simulations) of the projected changes. Error bars: $66 \%$ range of the simulations (original design by B. Gálos, method of calculation described in [6]).

The presence of silver fir has significantly declined in Central Europe in the past century, but only partly for climatic reasons, as acid rain and game damage contributed to the damages. After the reduction of air pollution across whole East-Central Europe, silver fir recovered significantly despite recent severe droughts. Regarding the future resilience of silver fir, the assessments of its expected response are incongruent. According to some opinions, the species may benefit from winter warming but may suffer from increasing summer droughts, particularly in poor sites at lower elevations [11,12]. Conversely, more optimistic forecasts emphasize the relatively high resilience of silver fir and predict its survival even under increasing stress $[13,14]$. Furthermore, numerous studies suggest silver fir as a potential alternative species in ecosystems menaced by increasing droughts $[7,15-17,18]$. Introducing preadapted populations and even nonnative fir species that possess higher drought tolerance has also garnered increasing attention $[19,20]$. Assisted migration is an ultimate and still debated option [21], gradually finding approval in East-Central Europe. The unknown long-term adaptive capacity of 
populations transcending their original climatic niche limits is a reason for concern and challenges the sustainability of forests $[3,22]$.

Provenance trials offer a unique opportunity to explore the inherited potential and limitations of adaptability, allowing for conclusions about drought stress responses of populations exposed to climatic changes mimicked by geographical transfer [23,24]. Test sites close to the xeric (rear) edges of species distribution are particularly promising locations to analyze phenotypic responses to drought stress.

Although questioned by some authors $[25,26]$, the between-population adaptive diversity of silver fir has been proven in provenance tests, but the long-term potential of the species coping with the projected climatic scenarios has not been sufficiently explored. Many of the existing studies were written before gridded climate data became available (e.g., [27-30]). Some results originate from greenhouse/nursery trials [25,31-33] or tests at juvenile age [34]. Since the advent of advanced analysis methods, a plethora of genomic, evolutionary, ecological, phenological, and physiological data improve the awareness of factors determining the adaptation of populations. Concurrent to the adaptive origin of differentiation, interfering historic/evolutionary effects are frequently discussed [35-37]. The assessment of phenological responses in the setting of projected climatic conditions, a precondition for management decisions is, however, still missing.

In this study we concentrate on a single phenotypical trait, height measured at an advanced age, to evaluate long-term adaptive responses of fir species and provenances. We apply a robust climate index to infer drought tolerance profiles for current and future conditions. The aim was to fill the existing gap between experimentally determined adaptive potential and predictions needed for management decisions [6]. The study is based on the reanalysis of results of three older provenance trials of fir species in the Czech Republic [20]. The specific value of the data, measured at an advanced age, justified a closer investigation of the phenotypic response of populations to climatic warming and droughts. The populations in the three trials include provenances of different Abies species of regional interest for adaptation/mitigation decisions in forestry practice. Native silver fir was the focus, represented by provenances from the drought-threatened part of the distribution in sub-continental East-Central Europe. The trials also contain other fir species from Southern Europe and from the American Northwest, which could be of potential use for future introductions.

First, we focused on detecting responses to the climatic conditions the populations were exposed to in the trials rather than on the ranking of populations. Height at an advanced age was interpreted as the joint result of the selection driven by past climatic factors at origin and by the response to "current" climate from planting until the last measurement. Geographic provenance data were used exclusively in the context of climatic factors; thus, transfer distances were expressed only in climatic terms. Second, a climate indicator available from harmonized, gridded datasets for selected time periods was chosen to model the observed and predicted responses. Climate projections were derived uniformly for the trial sites and the locations of origin. Third, drought tolerance profiles established in the trials were utilized to estimate the potential of fir species and provenances in the setting of a selected climate scenario for the subcontinental zone in East-Central Europe.

\section{Materials and Methods}

\subsection{Description of the Three Provenance Trials}

The Forestry and Game Management Research Institute (FGMRI) established three provenance trials of fir species in the Czech Republic between 1976 and 1984. The trials contain a selection of provenances of Euro-Mediterranean and North American species $[38,39]$. The Písek trial, organized by the FGMRI, contains native silver fir (A. alba Mill.) and other fir species from the Balkan and the Mediterranean (Table 3). As part of a series initiated by IUFRO, an extensive collection of 24 coastal and inland provenances of grand 
fir (A. grandis (Dougl. Ex D. Don) Lindl.) was established in Zbiroh (Table 4). The trial Dražičky, belonging to another international IUFRO series, contains provenances of grand fir and noble fir (A. procera Rehder) (Table 5). (Latin names are used in the text only for the less known Balkan and Mediterranean fir species.) Geographic data and maps of the populations' provenance, historic and site details of the trials, as well as all data measured in 2015 are found in Frýdl et al. [20].

Similar to most other provenance tests, the trials are far from being fully representative for any of the species and make only limited comparisons possible. The specific value of these trials is that they were maintained and measured until nearly mature age (32 to 40 years), and, even more importantly, the trials are typically located in climatic environments close to the warm and dry xeric limits of silver fir. (The term xeric limit is preferred as an alternative for rear or trailing limit, to describe the low-elevation, drought-threatened limit of distribution to emphasize the primary role of water scarcity at these borders.) The chosen low-elevation sites were nearly offsite conditions for some Abies species and provenances. Such data are very rare and facilitate the "space-for-time" assessment of growth and resilience, even in the absence of mortality observations.

\subsection{Source of Data and Method of Analysis}

The data of measurements from 2015, which are the basis of the present analysis, have been evaluated by the FGMRI and published by Frýdl et al. [20]. The three trials were investigated individually due to different sets of species and populations. From among the different quantitative traits observed, height consequently yielded the lowest error variation and the best differentiation among populations. In genetic field tests, the high heritability of height has proven its relative independence from environmental and human-caused effects. Therefore, mean height was selected to investigate the sensitivity of provenances to drought.

Phenotypic responses were interpreted as effects of climatic change mimicked by geographic transfer and analyzed by applying the ecodistance concept [24]. "Ecodistance" (here: climatic transfer distance) is defined as the difference between the ecologically relevant variables (in this case, climate) at the test site and the population provenance (origin); i.e., the difference between the conditions undergone by the populations in the experiment and the conditions they had adapted to in the past. Positive differences indicate a transfer to drier and/or warmer sites (=mimicked climatic warming); negative values signify transfer to cooler and/or wetter sites (=mimicked climatic cooling). The 0 value stands for a climate equivalent to that at the site of provenance [40].

Table 1. Basic data of the three trials and their mean height and tree density in 2015. Adapted from [20].

\begin{tabular}{lccccccc}
\hline $\begin{array}{c}\text { Trial } \\
\text { Name }\end{array}$ & $\begin{array}{c}\text { Year of } \\
\text { Planting }\end{array}$ & $\begin{array}{c}\text { Altitude Longitude } \\
(\mathbf{m})\end{array}$ & $\begin{array}{c}\text { Latitude } \\
\text { (Decimal) } \\
\text { (Decimal) }\end{array}$ & $\begin{array}{c}\text { Age at } \\
\text { Measurement } \\
\text { (years) }\end{array}$ & $\begin{array}{c}\text { Trial } \\
\text { Mean } \\
\text { Height } \\
\text { (m) }\end{array}$ & $\begin{array}{c}\text { Mean Tree } \\
\text { Density } \\
\text { (\% from } \\
\text { Planted) }\end{array}$ \\
\hline Písek & 1976 & 395 & $14.33^{\circ} \mathrm{E}$ & $49.27^{\circ} \mathrm{N}$ & 40 & 15.49 & $28.5^{\text {a }}$ \\
Zbiroh & 1980 & $450-460$ & $13.64^{\circ} \mathrm{E}$ & $49.79^{\circ} \mathrm{N}$ & 36 & 19.26 & 50.1 \\
Dražičky & 1984 & 485 & $14.59^{\circ} \mathrm{E}$ & $49.39^{\circ} \mathrm{N}$ & 32 & 14.54 & 55.9 \\
\hline
\end{tabular}

${ }^{a}$ without three Mediterranean populations, showing $100 \%$ mortality.

Climatic transfer distance is interpreted as the indicator of relative drought, individually undergone by populations at the test site, compared to the drought stress they were adapted to in the past. In this sense, the value of relative drought is different for every provenance. To determine climatic transfer distances, the mean of the period from outplanting until the time of measurement was calculated for the "current climate" conditions at the test site. The length of the averaged period was different for each test 
because the planting years varied, while measurements were made in the same year, in 2015 (Table 1). The reference period for the "past climate at provenance" was set uniformly for 1911-1940. The selected 30-year period covers roughly the middle third of the approximate age (80-100 years) of selected populations from which seeds were harvested. At that age, within-population competition has largely formed the genetic structure of the stand. Climate analyses also indicate that this is the last time period of the Holocene before the onset of global anthropogenic effects [41,42]. Thus, it was taken as the basis for representing past secular adaptation.

Accordingly, climatic transfer distance, i.e., relative drought, was determined for climatic moisture deficit $(d C M D)$ as

$$
d C M D=[\text { current value at test site }]-[\text { past value at provenance }]
$$

The "current climate" of the Czech test sites was determined using the data of nearby (Czech) meteorological stations. The distances to the nearest meteorological stations were small, and corrections were unnecessary (Table A1). In this study, year-to-year growth (increment) variations or annual weather fluctuations were not the objects of analyses as the focus was on height response attained at the final measurement, determined by longterm means. Besides the annual precipitation and temperature fluctuations, the weather conditions in the course of the trial maintenance have also shown a significant trend of rising temperatures and recurrent drought years. Summer temperature means at the trial sites of Písek and Dražičky increased by $1.3^{\circ} \mathrm{C}$, from 16.6 to $17.9^{\circ} \mathrm{C}$. At the Zbiroh site, the increase reached $1.9^{\circ} \mathrm{C}$. Extremely hot summers were observed at all three trial sites in the years 1992, 1994, 2003, and 2015. Consequently, the climatic moisture deficit has increased during the "current" climate period in all three trials. Nevertheless, the extreme weather conditions did not lead to conspicuous mortality differentiation, with the exception of the Mediterranean fir species in the Písek trial.

Data for past climates were obtained from two databases. For the EuroMediterranean locations, the recently published database ClimateEU (version 4.80) [43] was utilized. It contains historic climate data for Europe using 15 global climate models, for a representative set of climate variables, for the last 120 years (1901 to 2019) as well as multi-model CMIP5 climate change projections for the 21st century. The similarly developed software package ClimateWNA (version July 2020) [44], which also contains historical data and future projections, served to downscale past climate variables for western North American populations of firs in the trials. Scale-free, actualized climate datasets from both databases were downscaled courtesy of T. Wang (UBC Vancouver). During the course of the digital interpolation of past climate data, it became apparent that in numerous cases the original coordinates of sampled forest stands were incorrect. Consequently, the nearest point at proper altitude served to estimate the climate parameters; the actual land cover shown on Google was taken also into consideration. Climate data and executed corrections are indicated in Tables 3-5. Due to the different methods of determining climate parameters, the climate data in this study are not identical to those in Frýdl et al. [20].

Hargreaves' climatic moisture deficit $(C M D)$ was selected to calculate the climatic transfer distances. This bioclimatic variable was calibrated originally for estimating potential evaporation relative to precipitation under semi-arid agrarian conditions [45]. Comparisons of results with other, straightforward variables have indicated that $C M D$ is also well suited for describing drought stress under forest conditions. The comparison of response regressions using $C M D$ values both for annual and summer periods surprisingly indicated that annual $C M D$ values yielded higher determination coefficients, so these were selected for the calculation of climatic transfer distances ( $\left.d C M D_{\mathrm{ann}}\right)$. Hargreaves' CMD means of 30-year periods were available from both databases (ClimateEU and ClimateWNA). The climatic transfer distances expressed as differences of CMD values $(d C M D)$ were calculated not only for current vs past climates but also for future climatic changes. The transfer distances of the two basic variables, temperature, and precipitation, 
are shown in Appendix A to illustrate their contribution to the responses at the test sites (Figures A1-A3).

The statistical analysis of the trials was performed using the QC.Expert 3.1 [46] and NCSS 10 (version: 10.0.6) programs [20]. Due to the non-normality of the data, the differences among provenances were tested using the Kruskal-Wallis one-way ANOVA test. Regressions were calculated between height and climatic transfer distance of provenances// but were presented only if statistically significant and biologically appropriate. These tolerance profiles are transfer functions (even if shown only as scatter of data points), comparing the responses of different populations in the same common garden test. They have to be distinguished from reaction norms of individual populations expressing their phenotypic plasticity across numerous test sites [40]. Lacking data of similar-age parallel trials, the results did not allow for the calculation and comparison of reaction norms. However, the tolerance profile of species, i.e., the variation of phenotypic response between differently adapted provenances, offers a hint to estimate the speciesspecific range of climatic resilience and allows certain comparisons between species.

\section{Results}

Tables 1 and 2 show the main data of the test sites and their mean height and mean density (remaining percentage from planted) measured in 2015. Tree density numbers were the lowest at the driest site Písek, partly due to the higher age of the trial. The density data could not be used for inferring survival differentiation between provenances. The reasons were the absence of extreme events triggering significant mortality and the routine silvicultural tendings, applied to keep relatively even competition conditions in the trials. Partly due to the relatively small plot size for the advanced-age trees, the rather strong differentiation of tree numbers per plot could not be linked to climate factors, with a few exceptions (discussed later).

Table 2. Current climate parameters of the three provenance tests, calculated according to the described protocol.

\begin{tabular}{lccccc}
\hline Trial Name & $\begin{array}{c}\text { Annual Mean } \\
\text { Temp. } \\
\left({ }^{\circ} \mathbf{C}\right)\end{array}$ & $\begin{array}{c}\text { Mean Temp. Annual Mean } \\
\text { in Warmest } \\
\text { Quarter }\left({ }^{\circ} \mathbf{C}\right)\end{array}$ & $\begin{array}{c}\text { Mrecip. } \\
\text { (mm) }\end{array}$ & $\begin{array}{c}\text { Mean } \\
\text { Precip. in } \\
\text { Warmest } \\
\text { Quarter (mm) }\end{array}$ & $\begin{array}{c}\text { Mean Annual } \\
\text { Moisture } \\
\text { Deficit } \\
\left(\text { CMD }_{a n n)}\right)\end{array}$ \\
\hline Písek & 8.1 & 17.2 & 570 & 229 & 213 \\
Zbiroh & 8.1 & 17.0 & 595 & 241 & 179 \\
Dražičky & 8.1 & 17.3 & 592 & 229 & 189 \\
\hline
\end{tabular}

The results of the Kruskal-Wallis one-way ANOVA tests rejected the hypothesis of equal mean heights at the $p \leq 0.05$ level for all three experiments. Matrices of significance, based on the obtained statistics are presented in Appendix A in Figures A4-A6. The statistics have proven significant differences mostly at the level of provenance groups. The significance of differences might be underestimated due to the applied one-way ANOVA test.

Contemplating climatic transfer distances $\left(d C M D_{\text {ann }}\right)$, i.e., relative drought values at the trial sites, annual climatic moisture supply was sufficient or even advantageous for some populations, first due to the summer rainfall maxima typical for Central Europe. Table 2 summarizes the main climatic data of the three Czech test sites for the "current climate" period. Data of provenances are presented in Tables 3 to 5. 
Table 3. Basic data of the provenance trial 64, Písek: species and populations represented and basic data used for analysis (sequence and geographic data of provenances are identical to the source publication (Adapted partly from [20]). Climate distances refer to the trial location.

\begin{tabular}{|c|c|c|c|c|c|c|c|c|c|c|c|c|c|c|c|c|}
\hline \multicolumn{6}{|c|}{ Populations of the Provenance Trial 64 Písek, CZ } & \multicolumn{6}{|c|}{ Past Climate at Origin (1911-1940) } & \multicolumn{3}{|c|}{ Climate Distance (D) } & \multicolumn{2}{|c|}{ Data 2015} \\
\hline $\begin{array}{l}\text { Prov } \\
\text { No. }\end{array}$ & $\begin{array}{c}\text { Abies Species } \\
\text { Name }\end{array}$ & Provenance Name & $\begin{array}{l}\text { Alt. } \\
\text { (m) }\end{array}$ & $\begin{array}{l}\text { Long. } \\
\mathrm{E}\end{array}$ & $\begin{array}{l}\text { Lat. } \\
\text { N }\end{array}$ & $\begin{array}{c}\text { January } \\
\text { Mean } \\
\text { Temp. } \\
\left({ }^{\circ} \mathrm{C}\right)\end{array}$ & $\begin{array}{c}\text { Annual } \\
\text { Mean } \\
\text { Temp. } \\
\left({ }^{\circ} \mathrm{C}\right)\end{array}$ & $\begin{array}{c}\text { Mean } \\
\text { Temp. } \\
\text { Warmest } \\
\text { Quarter } \\
\left({ }^{\circ} \mathrm{C}\right)\end{array}$ & $\begin{array}{c}\text { Annua } \\
\text { Mean } \\
\text { Prec. } \\
(\mathrm{mm})\end{array}$ & $\begin{array}{c}\text { Mean } \\
\text { Prec. } \\
\text { Warmest } \\
\text { Quarter } \\
(\mathrm{mm})\end{array}$ & $\begin{array}{l}C M D \\
\text { (mm, } \\
\text { Ann.) }\end{array}$ & $\begin{array}{c}\text { Temp. } \\
\text { Change } \\
\text { Warmest } \\
\text { Quarter } \\
\left({ }^{\circ} \mathrm{C}\right)\end{array}$ & $\begin{array}{c}\text { Prec. } \\
\text { Change } \\
\text { t Warmest } \\
\text { Quarter } \\
(\mathrm{mm})\end{array}$ & $\begin{array}{c}d C M D \\
\text { (Index } \\
\text { Change, } \\
\mathrm{mm} \text { ) }\end{array}$ & $\begin{array}{c}\text { Mean } \\
\text { Height } \\
\text { (m) }\end{array}$ & 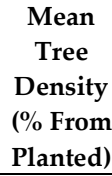 \\
\hline 74 & A. alba & Milevsko, $\mathrm{Kl}$ & 410 & $14.2^{\circ}$ & $49.6^{\circ}$ & -2 & 8.4 & 17.3 & 492 & 189 & 284 & -0.1 & 40.0 & -71 & 17.19 & 22.0 \\
\hline 81 & A. alba & Vyšší Brod, Vítkův Kámen CZ & 900 & $14.3^{\circ}$ & $48.6^{\circ}$ & -4.2 & 5.9 & 14.5 & 854 & 296 & 122 & 2.7 & -67.0 & 91 & 15.47 & 10.0 \\
\hline $89 *$ & A. cilicica & Kammouha LIB & 1100 & $36.0^{\circ}$ & $34.0^{\circ}$ & 6.3 & 14.9 & 22.2 & 1167 & 4 & 763 & -5.0 & 225.0 & -550 & 0.00 & 0.0 \\
\hline 109 & A. cephalonica & Centr. Peloponnese, Vy & 1250 & $22.1^{\circ}$ & $37.6^{\circ}$ & 1.9 & 10.9 & 18.7 & 794 & 51 & 573 & -1.5 & 178.0 & -360 & 14.19 & 29.3 \\
\hline 121 * & A. cilicica & Djebel el Chouk, Lattakia SYR & 1300 & $36.0^{\circ}$ & $35.8^{\circ}$ & 2.2 & 12.6 & 20 & 1039 & 24 & 525 & -2.8 & 205.0 & -312 & 0.00 & 0.0 \\
\hline 130 & A. alba & Nasavrky, Podhůra CZ & 370 & $15.8^{\circ}$ & $49.8^{\circ}$ & -2.7 & 8.2 & 16.8 & 487 & 196 & 253 & 0.4 & 33.0 & -40 & 16.89 & 32.7 \\
\hline $132 *$ & A. alba & Rilskije gory, Borovec BG & 1200 & $23.6^{\circ}$ & $42.2^{\circ}$ & -3 & 7.3 & 15.7 & 515 & 137 & 362 & 1.5 & 92.0 & -149 & 16.85 & 31.3 \\
\hline $135^{*}$ & A. pinsapo & Malaga, La Yunquera ES & 878 & $4.7^{\circ} \mathrm{W}$ & $36.7^{\circ}$ & 6.8 & 14.7 & 22.2 & 633 & 18 & 711 & -5.0 & 211.0 & -498 & 0.00 & 0.0 \\
\hline 136 & A. cephalonica & Peloponnese, Vytina GR & 1010 & $22.2^{\circ}$ & $37.7^{\circ}$ & 3.4 & 12.2 & 20 & 753 & 48 & 626 & -2.8 & 181.0 & -413 & 14.34 & 34.7 \\
\hline $137^{*}$ & A. borisii-regis & Mt. Pindos, Pertuli GR & 1200 & $21.3^{\circ}$ & $39.8^{\circ}$ & -0.3 & 9.6 & 18.2 & 727 & 88 & 503 & -1.0 & 141.0 & -290 & 14.59 & 35.3 \\
\hline $223^{*}$ & A. alba & Sanski Most BH & 1050 & $16.6^{\circ}$ & $44.6^{\circ}$ & -3.5 & 6.9 & 15.3 & 943 & 226 & 170 & 1.9 & 3.0 & 43 & 15.61 & 28.0 \\
\hline $228^{*}$ & A. alba & Regello, Vallombrosa IT & 1010 & $11.5^{\circ}$ & $43.7^{\circ}$ & 0.2 & 9.5 & 17.5 & 967 & 163 & 180 & -0.3 & 66.0 & 33 & 14.82 & 30.7 \\
\hline $\mathrm{S} 2 *$ & A. alba & Banská Bystrica, Radvaň SK & 780 & $19.0^{\circ}$ & $48.7^{\circ}$ & -5.1 & 6.4 & 15.1 & 759 & 258 & 152 & 2.1 & -29.0 & 61 & 14.92 & 31.3 \\
\hline & Data and curr & nt climate of the test site ** & 395 & $14.3^{\circ}$ & $49.2^{\circ}$ & -1.5 & 8.1 & 17.2 & 570 & 229 & 213 & & & & 15.49 & 28.5 \\
\hline
\end{tabular}

Climate data for Kammouha, LB were estimated from Worldclim database,1961-1990; ${ }^{*}$ Corrected locations ${ }^{* *}$ CZ met data (original or corrected). Last row: numbers in italics indicate averages excluding the populations with 0.0 values

Table 4. Basic data of the provenance trial 213 Zbiroh: location and climate of grand fir populations used for analysis (sequence and geographic data of provenances are identical to the source publication (Adapted partly from [20]). Climate distances refer to the trial location.

\begin{tabular}{|c|c|c|c|c|c|c|c|c|c|c|c|c|c|c|c|c|}
\hline \multicolumn{6}{|c|}{ Populations of the Provenance Trial 213 Zbiroh, CZ } & \multicolumn{6}{|c|}{ Past Climate at Origin (1911-1940) } & \multicolumn{3}{|c|}{ Climate Distance (D) } & \multicolumn{2}{|c|}{ Data 2015} \\
\hline $\begin{array}{l}\text { Prov } \\
\text { No. }\end{array}$ & $\begin{array}{c}\text { Abies Species } \\
\text { Name }\end{array}$ & Provenance Name & $\begin{array}{l}\text { Alt. } \\
\text { (m) }\end{array}$ & $\begin{array}{l}\text { Long. } \\
\text { W }\end{array}$ & $\begin{array}{l}\text { Lat. } \\
\text { N }\end{array}$ & $\begin{array}{c}\text { January } \\
\text { Mean } \\
\text { Temp. } \\
\left({ }^{\circ} \mathrm{C}\right)\end{array}$ & $\begin{array}{c}\text { Annual } \\
\text { Mean } \\
\text { Temp. } \\
\left({ }^{\circ} \mathrm{C}\right)\end{array}$ & $\begin{array}{c}\text { Mean } \\
\text { Temp. } \\
\text { Warmest } \\
\text { Quarter } \\
\left({ }^{\circ} \mathrm{C}\right)\end{array}$ & $\begin{array}{l}\text { Annual } \\
\text { Mean } \\
\text { Prec. } \\
(\mathrm{mm})\end{array}$ & $\begin{array}{c}\text { Mean } \\
\text { Prec. } \\
\text { Warmest } \\
\text { Quarter } \\
(\mathrm{mm})\end{array}$ & $\begin{array}{l}C M D \\
\text { t (mm, } \\
\text { ann.) }\end{array}$ & $\begin{array}{c}\text { Temp. } \\
\text { Change } \\
\text { Warmest } \\
\text { Quarter } \\
\left({ }^{\circ} \mathrm{C}\right) \\
\end{array}$ & $\begin{array}{c}\text { Prec. } \\
\text { Change } \\
\text { Warmest } \\
\text { Quarter } \\
\text { (mm) }\end{array}$ & $\begin{array}{c}d C M D \\
\text { (Index } \\
\text { Change, } \\
\text { mm) }\end{array}$ & $\begin{array}{c}\text { Mean } \\
\text { Height } \\
\text { (m) }\end{array}$ & $\begin{array}{c}\text { Mean } \\
\text { Tree } \\
\text { Density } \\
\text { (\% from } \\
\text { Planted) }\end{array}$ \\
\hline 12040 & A. grandis & Salmon River CAN/BC* & 50 & $125.8^{\circ}$ & $50.3^{\circ}$ & 0.6 & 8.4 & 15.6 & 1444 & 150 & 211 & 1.4 & 91.0 & -32 & 21.81 & 44.0 \\
\hline 12041 & A. grandis & Oyster Bay CAN/BC & 5 & $125.2^{\circ}$ & $49.9^{\circ}$ & 1.2 & 9.1 & 16.3 & 1137 & 121 & 286 & 0.7 & 120.0 & -107 & 20.90 & 70.0 \\
\hline 12042 & A. grandis & Buckley Bay CAN/BC & 45 & $124.9^{\circ}$ & $49.5^{\circ}$ & 0 & 8.8 & 16.3 & 1391 & 87 & 319 & 0.7 & 154.0 & -140 & 19.32 & 62.0 \\
\hline 12043 & A. grandis & Sproat Lake CAN/BC & 25 & $125.0^{\circ}$ & $49.3^{\circ}$ & 0.8 & 9.4 & 17 & 1827 & 117 & 293 & 0.0 & 124.0 & -114 & 20.05 & 58.0 \\
\hline 12044 & A. grandis & Kay Road CAN/BC & 50 & $124.3^{\circ}$ & $49.3^{\circ}$ & 2 & 9.4 & 16.5 & 863 & 85 & 342 & 0.5 & 156.0 & -163 & 20.02 & 72.0 \\
\hline 12045 & A. grandis & Yellow Point CAN/BC & 30 & $123.8^{\circ}$ & $49.1^{\circ}$ & 2.7 & 9.7 & 16.6 & 916 & 81 & 335 & 0.4 & 160.0 & -156 & 20.03 & 57.0 \\
\hline 12046 & A. grandis & Mount Provost CAN/BC & 75 & $123.8^{\circ}$ & $48.8^{\circ}$ & 1.8 & 9.5 & 16.7 & 1199 & 78 & 353 & 0.3 & 163.0 & -174 & 21.38 & 63.0 \\
\hline
\end{tabular}




\begin{tabular}{|c|c|c|c|c|c|c|c|c|c|c|c|c|c|c|c|}
\hline 12047 A. grandis & Sooke CAN/BC & 20 & $123.8^{\circ}$ & $48.4^{\circ}$ & 2.9 & 9.6 & 14.9 & 1111 & 72 & 296 & 2.1 & 169.0 & -117 & 20.05 & 60.0 \\
\hline 12002 A. grandis & Tulalip USA/WA & 30 & $122.3^{\circ}$ & $48.1^{\circ}$ & 3.4 & 9.5 & 14.8 & 651 & 53 & 369 & 2.2 & 188.0 & -190 & 22.29 & 48.0 \\
\hline 12003 A. grandis & Indian Creek USA/WA & 140 & $123.6^{\circ}$ & $48.1^{\circ}$ & 2.1 & 9 & 14.7 & 1011 & 64 & 334 & 2.3 & 177.0 & -155 & 21.48 & 57.0 \\
\hline 12004 A. grandis & Gardiner USA/WA & 30 & $122.9^{\circ}$ & $48.1^{\circ}$ & 2.9 & 9.6 & 15.2 & 497 & 61 & 401 & 1.8 & 180.0 & -222 & 21.72 & 56.0 \\
\hline 12006 A. grandis & Eagle Creek-low USA/WA* & 760 & $120.6^{\circ}$ & $47.7^{\circ}$ & -4.2 & 7.6 & 17.8 & 831 & 56 & 531 & -0.8 & 185.0 & -352 & 19.05 & 46.0 \\
\hline 12008 A. grandis & Jack Creek USA/WA* & 825 & $120.8^{\circ}$ & $47.3^{\circ}$ & -3.7 & 6.6 & 15.9 & 877 & 56 & 487 & 1.1 & 185.0 & -308 & 17.30 & 43.0 \\
\hline 12011 A. grandis & Clear Lake USA/WA* & 945 & $121.3^{\circ}$ & $46.6^{\circ}$ & -3.8 & 5.4 & 14 & 948 & 69 & 394 & 3.0 & 172.0 & -215 & 17.89 & 48.0 \\
\hline 12013 A. grandis & Cooper Spur USA/OR & 1040 & $121.7^{\circ}$ & $45.5^{\circ}$ & -1.9 & 6.7 & 14.8 & 2097 & 115 & 232 & 2.2 & 126.0 & -53 & 18.91 & 36.0 \\
\hline 12015 A. grandis & Sisi Butte USA/OR* & 975 & $121.8^{\circ}$ & $44.9^{\circ}$ & -0.8 & 7.4 & 15.2 & 1595 & 98 & 318 & 1.8 & 143.0 & -139 & 18.19 & 36.0 \\
\hline 12016 A. grandis & Santiam Summit USA/OR & 1400 & $121.9^{\circ}$ & $44.4^{\circ}$ & -2.2 & 5.5 & 13.1 & 2033 & 127 & 266 & 3.9 & 114.0 & -87 & 16.22 & 34.0 \\
\hline 12019 A. grandis & Roaring River USA/OR* & 1310 & $122.0^{\circ}$ & $43.5^{\circ}$ & -0.7 & 6.8 & 14.3 & 1733 & 129 & 286 & 2.7 & 112.0 & -107 & 17.88 & 24.0 \\
\hline 12020 A. grandis & Crescent Creek USA/OR* & 1375 & $121.9^{\circ}$ & $43.5^{\circ}$ & -2.7 & 5.7 & 13.6 & 782 & 56 & 524 & 3.4 & 185.0 & -345 & 17.90 & 24.0 \\
\hline 12025 A. grandis & Buckskin Creek USA/ID* & 1220 & $116.2^{\circ}$ & $48.0^{\circ}$ & -5.4 & 4.8 & 14.4 & 1087 & 129 & 304 & 2.6 & 112.0 & -125 & 14.55 & 56.0 \\
\hline 12026 A. grandis & Plummer Hill USA/ID & 850 & $116.9^{\circ}$ & $47.3^{\circ}$ & -3.2 & 7.6 & 17.3 & 642 & 80 & 511 & -0.3 & 161.0 & -332 & 16.96 & 20.0 \\
\hline 12031 A. grandis & Bertha Hill USA/ID* & 1430 & $115.8^{\circ}$ & $46.8^{\circ}$ & -4.4 & 5.7 & 15.5 & 1341 & 120 & 307 & 1.5 & 121.0 & -128 & 18.17 & 63.0 \\
\hline 12038 A. grandis & Clearwater USA/ID* & 760 & $115.4^{\circ}$ & $46.6^{\circ}$ & -3.5 & 7.9 & 18.3 & 965 & 114 & 479 & -1.3 & 127.0 & -300 & 21.48 & 72.0 \\
\hline 12037 A. grandis & Stanley Creek USA/MT* & 800 & $115.9^{\circ}$ & $48.3^{\circ}$ & -5.4 & 6.1 & 16.1 & 698 & 97 & 494 & 0.9 & 144.0 & -315 & 18.58 & 53.0 \\
\hline D & $\mathrm{ma}$ & 456 & $\begin{array}{c}13.64^{\circ} \\
\mathrm{E}\end{array}$ & 4 & .4 & 8.1 & 17.0 & 595 & 241 & 179 & & & & 9.26 & 50.1 \\
\hline
\end{tabular}

Table 5. Basic data of the provenance trial 219 Dražičky: location and climate of species and populations used for analysis (sequence and geographic data of provenances are identical to the source publication (Adapted partly from [20]). Climate distances refer to the trial location.

\begin{tabular}{|c|c|c|c|c|c|c|c|c|c|c|c|c|c|c|c|c|}
\hline \multicolumn{6}{|c|}{ Populations of the Provenance trial 219 Dražičky, CZ } & \multicolumn{6}{|c|}{ Past Climate at Origin (1911-1940) } & \multicolumn{3}{|c|}{ Climate Distance (D) } & \multicolumn{2}{|c|}{ Data 2015} \\
\hline Prov $N$ & $\begin{array}{c}\text { Abies Species } \\
\text { Name }\end{array}$ & Provenance Origin, Name & $\begin{array}{l}\text { Alt. } \\
\text { (m) }\end{array}$ & $\begin{array}{l}\text { Long. } \\
\text { W }\end{array}$ & $\begin{array}{c}\text { Lat. } \\
\text { N }\end{array}$ & $\begin{array}{c}\text { January } \\
\text { Mean } \\
\text { Temp. } \\
\left({ }^{\circ} \mathrm{C}\right)\end{array}$ & $\begin{array}{c}\text { Annual } \\
\text { Mean } \\
\text { Temp. } \\
\left({ }^{\circ} \mathrm{C}\right)\end{array}$ & $\begin{array}{c}\text { Mean } \\
\text { Temp. } \\
\text { Warmest } \\
\text { Quarter } \\
\left({ }^{\circ} \mathrm{C}\right)\end{array}$ & $\begin{array}{l}\text { Annual } \\
\text { Mean } \\
\text { Prec. } \\
(\mathrm{mm})\end{array}$ & $\begin{array}{l}\text { Mean } \\
\text { Prec. } \\
\text { Warmest } \\
\text { Quarter } \\
(\mathrm{mm})\end{array}$ & $\begin{array}{l}C M D \\
\text { (mm, } \\
\text { ann.) }\end{array}$ & $\begin{array}{c}\text { Temp. } \\
\text { Change } \\
\text { Warmest } \\
\text { Quarter } \\
\left({ }^{\circ} \mathrm{C}\right)\end{array}$ & $\begin{array}{c}\text { Prec. } \\
\text { Change } \\
\text { Warmest } \\
\text { Quarter } \\
(\mathrm{mm})\end{array}$ & $\begin{array}{c}d C M D \\
\text { (Index } \\
\text { Change, } \\
\text { mm) }\end{array}$ & $\begin{array}{c}\text { Mean } \\
\text { Height } \\
\text { (m) }\end{array}$ & $\begin{array}{c}\text { Mean } \\
\text { Tree } \\
\text { Density } \\
\text { (\% from } \\
\text { Planted) } \\
\end{array}$ \\
\hline $\mathrm{CZ} 0$ & A. alba & Adršpach CZ & 620 & $16.1^{\circ} \mathrm{E}$ & $50.6^{\circ}$ & -5.1 & 6.2 & 14.6 & 590 & 231 & 137 & 2.7 & -2.0 & 52.0 & 6.22 & 32.0 \\
\hline 12001 & A. grandis & Buck Creek (Skamania) USA/WA & 400 & $121.4^{\circ}$ & $48.3^{\circ}$ & -0.6 & 8.5 & 16.5 & 2291 & 174 & 199 & 0.8 & 55.0 & -10.0 & 20.65 & 74.0 \\
\hline 12002 & A. grandis & Tulalip (Ellensburg) USA/WA & 30 & $122.3^{\circ}$ & $48.1^{\circ}$ & 3.4 & 10.2 & 16.1 & 909 & 111 & 296 & 1.2 & 118.0 & -107.0 & 19.75 & 66.0 \\
\hline 13004 * & A. procera & Mary's Peak USA/OR & 1065 & $123.6^{\circ}$ & $44.5^{\circ}$ & 2.8 & 9.6 & 16.1 & 3060 & 89 & 269 & 1.2 & 140.0 & -80.0 & 12.41 & 44.0 \\
\hline $13006^{*}$ & A. procera & Snow Peak USA/OR & 1060 & $122.6^{\circ}$ & $44.6^{\circ}$ & 1.5 & 7.9 & 14.3 & 2532 & 173 & 177 & 3.0 & 56.0 & 12.0 & 13.68 & 42.0 \\
\hline 13011 * & A. procera & Larch Mtn. USA/OR & 975 & $122.1^{\circ}$ & $45.5^{\circ}$ & -0.3 & 7.2 & 14.2 & 2969 & 209 & 157 & 3.1 & 20.0 & 32.0 & 14.42 & 68.0 \\
\hline 13014 * & A. procera & Red Mtn. USA/WA & 1220 & $121.8^{\circ}$ & $45.9^{\circ}$ & -2.4 & 5.4 & 13 & 2489 & 150 & 171 & 4.3 & 79.0 & 18.0 & 14.53 & 63.0 \\
\hline 13018 & A. procera & McKinley Lake USA/WA & 900 & $122.1^{\circ}$ & $46.6^{\circ}$ & -0.4 & 7 & 14.2 & 2175 & 184 & 162 & 3.1 & 45.0 & 27.0 & 15.16 & 64.0 \\
\hline $13021 *$ & A. procera & Stevens Pass USA/WA & 1000 & $121.1^{\circ}$ & $47.7^{\circ}$ & -3.8 & 5.1 & 13.2 & 2075 & 159 & 185 & 4.1 & 70.0 & 4.0 & 14.00 & 50.0 \\
\hline \multicolumn{3}{|c|}{ Data and current climate of the test site ${ }^{* *}$} & 488 & $14.59^{\circ} \mathrm{E}$ & $49.39^{\circ}$ & -1.8 & 8.1 & 17.3 & 592 & 229 & 189 & & & & 14.54 & 55.9 \\
\hline
\end{tabular}




\subsection{Comparison of Euro-Mediterranean Fir Species and Provenances in Trial 64, Písek}

The trial contains seven populations of silver fir and six other fir populations from Southern Europe and the Near East (Table 3). The silver fir (Abies alba L.) provenances represent a geographically and climatically differentiated set of locations, mostly from the drought-threatened subcontinental part of the species distribution, which enabled the modelling of the intra-specific effect of growing drought stress across climates. The species were separately analyzed.

Five out of the seven silver fir populations in the Písek test (Vyšší Brod/CZ, Sanski Most/BH, Banská Bystrica/SK, Borovec/BG and the Sub-Mediterranean Regello/IT) are higher-altitude provenances ( $>700 \mathrm{~m}$ a.s.l.), with lower annual temperatures and higher precipitation than at Písek, with the exception of the extremely dry location at Borovec/BG. The two Czech low-elevation sources ( $<500 \mathrm{~m}$ a.s.l., Milevsko and Nasavrky) were transferred to a climate similar to their origin (Table 3, Figure 2, Figure A1a,b). The Italian provenance is the only population outside the subcontinental climate zone (Figures 2 and 3$)$.

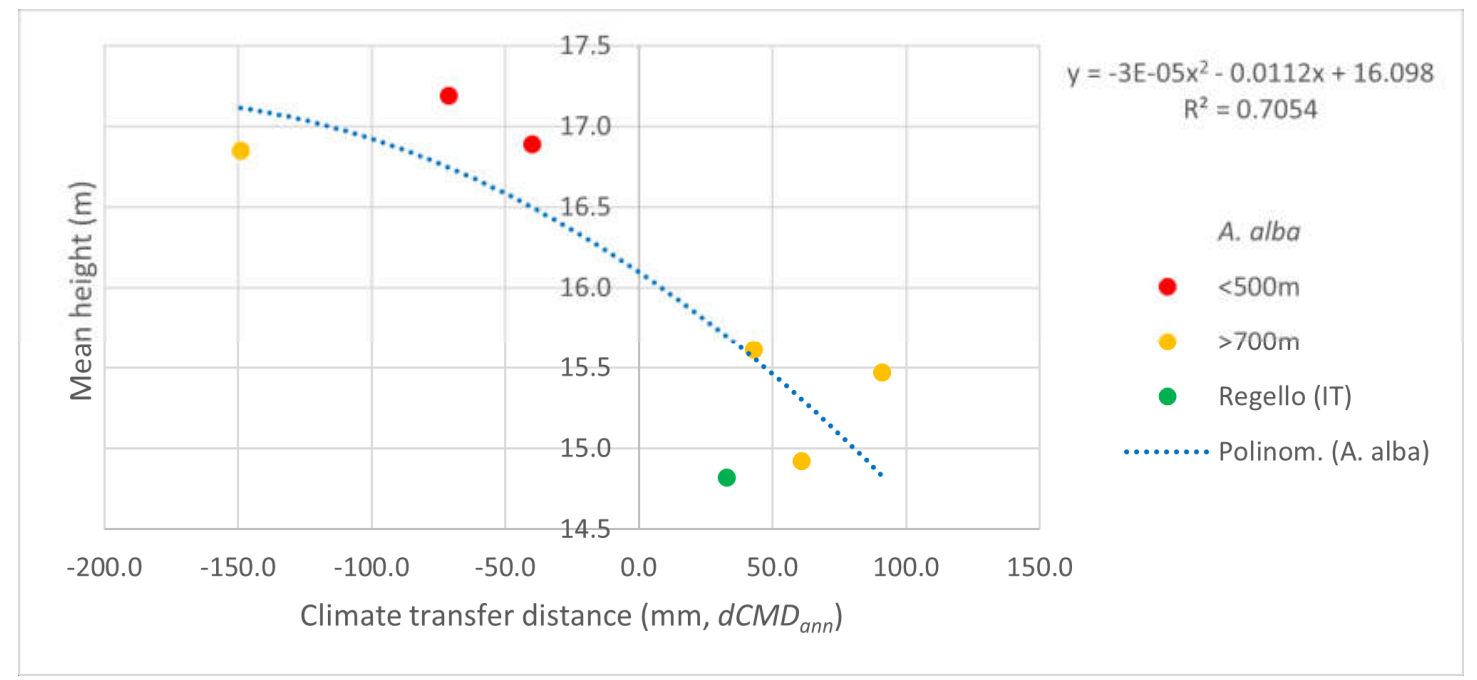

Figure 2. Mean height response and unilateral transfer equation of silver fir provenances to climate transfer distance (current vs past) expressed in annual moisture deficit units ( $\mathrm{mm}$ precipitation, $d C M D_{\mathrm{ann}}$ ) in the trial Písek. The regression is significant at $p \leq 0.05$.

Higher altitude provenances are adapted to less moisture deficit stress, appearing mainly during the summer months. Their transfer to the test site Písek caused increased exposure to relative (provenance-related) drought, causing weaker growth response. The low-elevation populations were more stressed at their origin, where the water supply deficit is also significant in the spring and autumn months. Their relative drought stress at Písek was less; thus, their height growth response was better. The response of the highelevation Bulgarian population from Borovec, Rila Mts. (1200 m a.s.l.) is specific; at its provenance annual precipitation is only $515 \mathrm{~mm}$, and the annual CMD amounts to 362 $\mathrm{mm}$. It is adapted to high moisture deficit also outside the summer season. Consequently, its response was similar to low-elevation populations, indicating high drought tolerance (Table 3, Figure 2). The Sub-Mediterranean population Regello (IT) displayed a weak drought tolerance close to the other high-elevation populations; its annual CMD at origin is just half of the Bulgarian provenance ( $180 \mathrm{~mm}$, Table 3 ).

Thus, a connection between height growth, respectively, drought tolerance at an older age, and the climate at origin to which the populations were adapted was detected. The annual $C M D$ values have shown a better correlation with height response than the summer values. The calculated regression is exponential and attains a significant $R^{2}$ value 
$(0.705, p \leq 0.05)$. The equation is unilateral, i.e., it shows the change of growth response towards only one limit of tolerance, here towards the xeric limit [40]. The regression mean height vs. $d C M D_{a n n}$ indicates the best height response for provenances with origins close to the test site, but the example of Borovec (BG) shows that transferred populations may attain similar performance. The result implies a considerable climate sensitivity of silver fir, which should be treated with caution as the result is based on only seven populations. The Kruskal-Wallis test matrix (Figure A4) supports the credibility of the result. The test demonstrated significant differences in height growth of silver fir by elevation and region; high elevation populations appeared set apart from the low-elevation Czech populations Milevsko and Nasavrky $(74,130)$, indicating effective local adaptation by altitude.

The comparison of all provenances in the Písek test shows a completely different picture (Figure 3). The three provenances from the Balkan species (A. borisii-regis, A. cephalonica, 109, 136, and 137) enjoyed a considerably cooler/wetter summer climate than at their origin. They responded with slower growth and shared this response with two silver fir populations transferred from locations further to the south than Písek; these are the high-elevation Slovak (S2 Radvaň) and Italian (228 Regello) populations. The KruskalWallis test confirmed their height growth to be significantly weaker, but there was no significant difference between them (Figure 3 and Figure A4). The climate tolerance profile of Balkan populations displays high moisture surplus (negative $d C M D_{a n n}$ ) values and does not show any trend linked to changing surplus moisture supply at Písek.

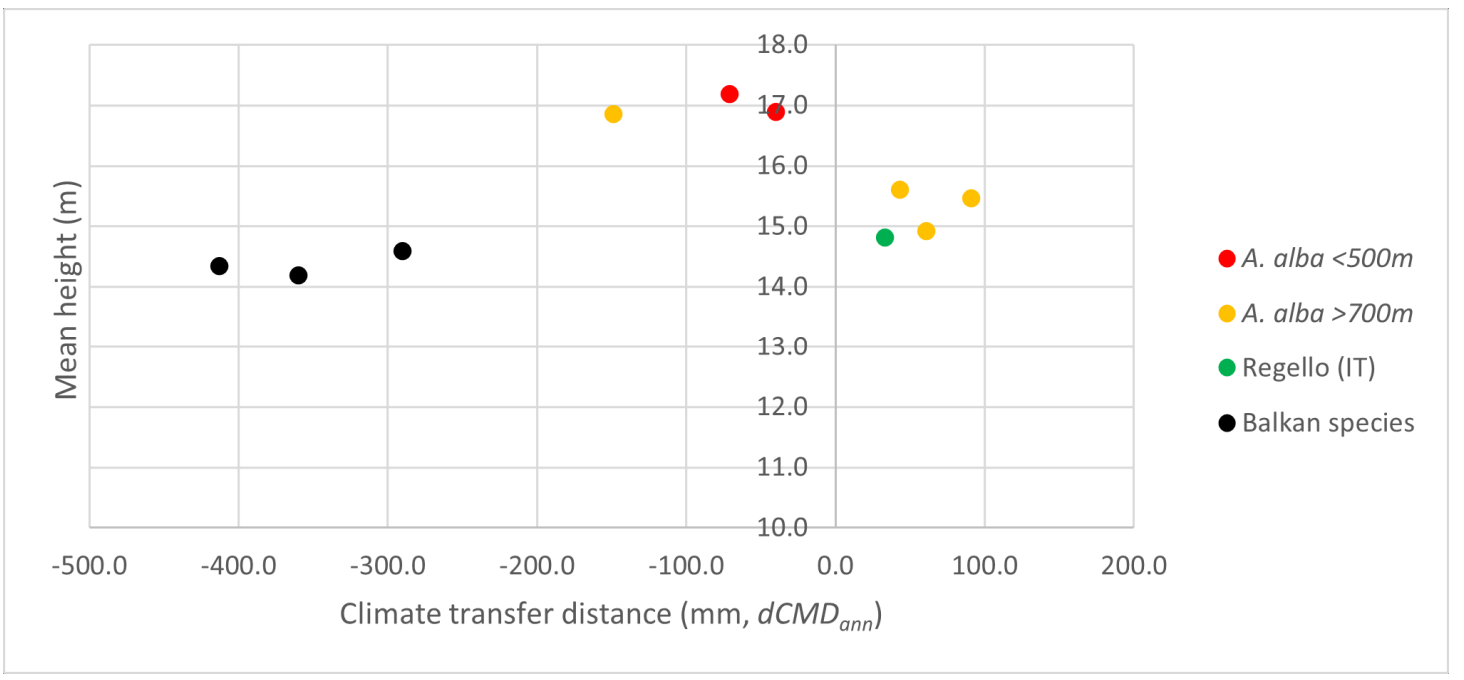

Figure 3. Mean height response of all provenances to climate transfer distance (current vs past) expressed in annual climatic moisture deficit ( $\mathrm{mm}$ precipitation $d C M D_{a n n}$ ) in the trial Písek. The provenances $A$. cilicica and A. pinsapo are not shown, having suffered total mortality (see also figures A1a and $\mathrm{b}$ for distances expressed in temperature and precipitation changes).

It is remarkable that $A$. cilicica and A. pinsapo populations from geographically distant and climatically extreme locations did not survive the climate of the test site (Table 3 ). The total mortality of these populations is most likely due to winter and late frosts, which were considerably harsher than at their original sites [38]. The January mean temperature at the origin of these populations is over $0^{\circ} \mathrm{C}\left(2.2-6.8^{\circ} \mathrm{C}\right)$, while the summer mean precipitation is extremely low; e.g., for A. cilicica from Kammouha, Lebanon, it amounts to only $4 \mathrm{~mm}$ (Table 3). The calculated high "surplus moisture" ( $d C M D_{a n n}$ in Table 3) played no role in preventing their mortality.

For the projection of future performance of silver fir provenances in the digital space of climate models, we used the unilateral transfer equation of silver fir, calculated for the "current climate" as a basis. Extending the equation for the periods 2041-2070 and 20712100 , estimations of height responses are achieved for the second half of the 21st century. 
For the sake of comparison, the future height data are shown uniformly for the age in the year 2015, i.e., in the sense of a site index at the age of 40 years, i.e., in 2015. The multimodel ensemble climate data in ClimateEU under the high-emission RCP8.5 and the less stringent mitigation RCP4.5 pathways were used both for the original locations of provenance and for the test site in Písek. The mid-century projections (2041-2070) did not show climatic changes substantial enough to warrant them being analyzed separately. Furthermore, only the results of the pathway RCP8.5 for the period 2071-2100 are displayed (Figure 4, Table A3). The pessimistic high-emission pathway was preferred as it was considered more realistic, considering also unknown physical and biological risks expected to affect the resilience of populations in the future.

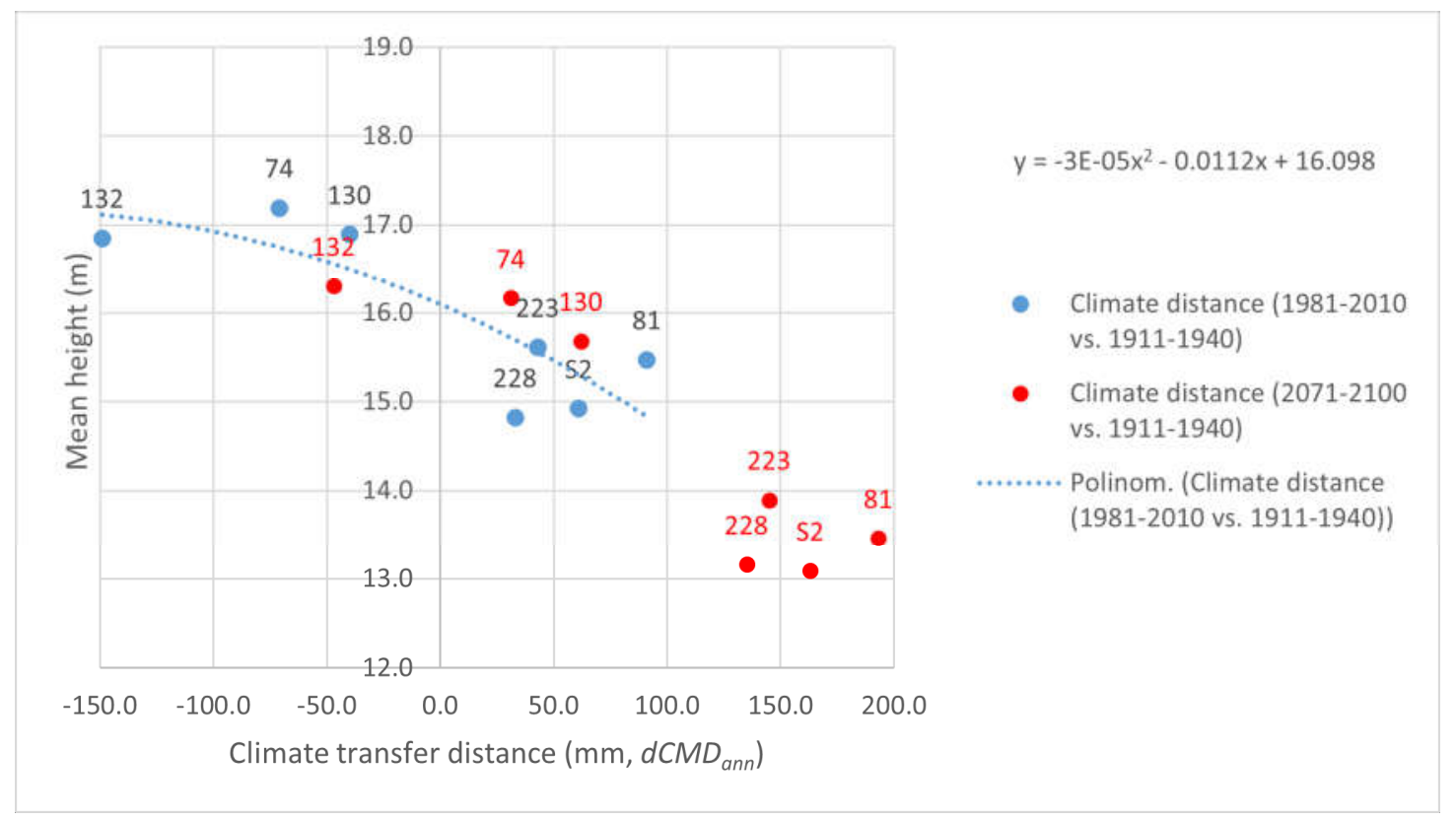

Figure 4. Current and the future climatic transfer distance and mean height response of silver fir provenances in the Písektrial. Their performance is compared under two transfer situations, current heights at the test site (data measured in 2015, blue dots) and projected heights (climate period 2071-2100, derived from ClimateEU, pathway RCP8.5, red dots). The transfer equation for current vs past climate was extrapolated for future data. The horizontal axis shows climate transfer distances (precipitation mm deficit). For the sake of comparison, current and future heights are both presented as the site index value for the age of 40 years, i.e., in 2015.

The projected response of the silver fir populations to the change of climate in the period 2071-2100 was calculated with the transfer equation gained for the current vs. past climates, assuming its validity for the whole century (Figure 4). The virtual transfer changed the climate distance by approximately $+100 \mathrm{~mm}$ moisture deficit increase for all populations. Height response shifts of provenances from current to future climates are basically of the same magnitude, but follow the exponential character of the equation; the height of the provenances that already had moisture deficits in the current climate experienced stronger declines under future conditions. The populations with extreme moisture deficit attained the lowest projected heights, and the responses reveal the most vulnerable populations. These are all high-altitude populations, adapted to milder drought stress of shorter duration: the Czech Vyšší Brod (81), the Slovak Radvaň (S2), further the Italian Regello (228) and the Bosnian Sanski Most (223). The high-altitude provenance Borovec (132) is adapted to a high moisture deficit at its origin and may attain a top position in Písek under the future climate (Table A3). No transfer equation is available for the Balkan fir species due to their currently sufficient moisture supply (Figure 3). Assuming a drought stress change of similar magnitude, i.e., a transfer shift $\left(d C M D_{a n n}\right)$ of approximately $100 \mathrm{~mm}$, all populations remain in the sufficient moisture 
supply zone in the period 2071-2100. This predicts a low drought stress exposure in the future for the high-altitude Balkan populations. The future performance of distant EuroMediterranean provenances cannot be estimated due to a lack of data in parallel test locations in milder climates.

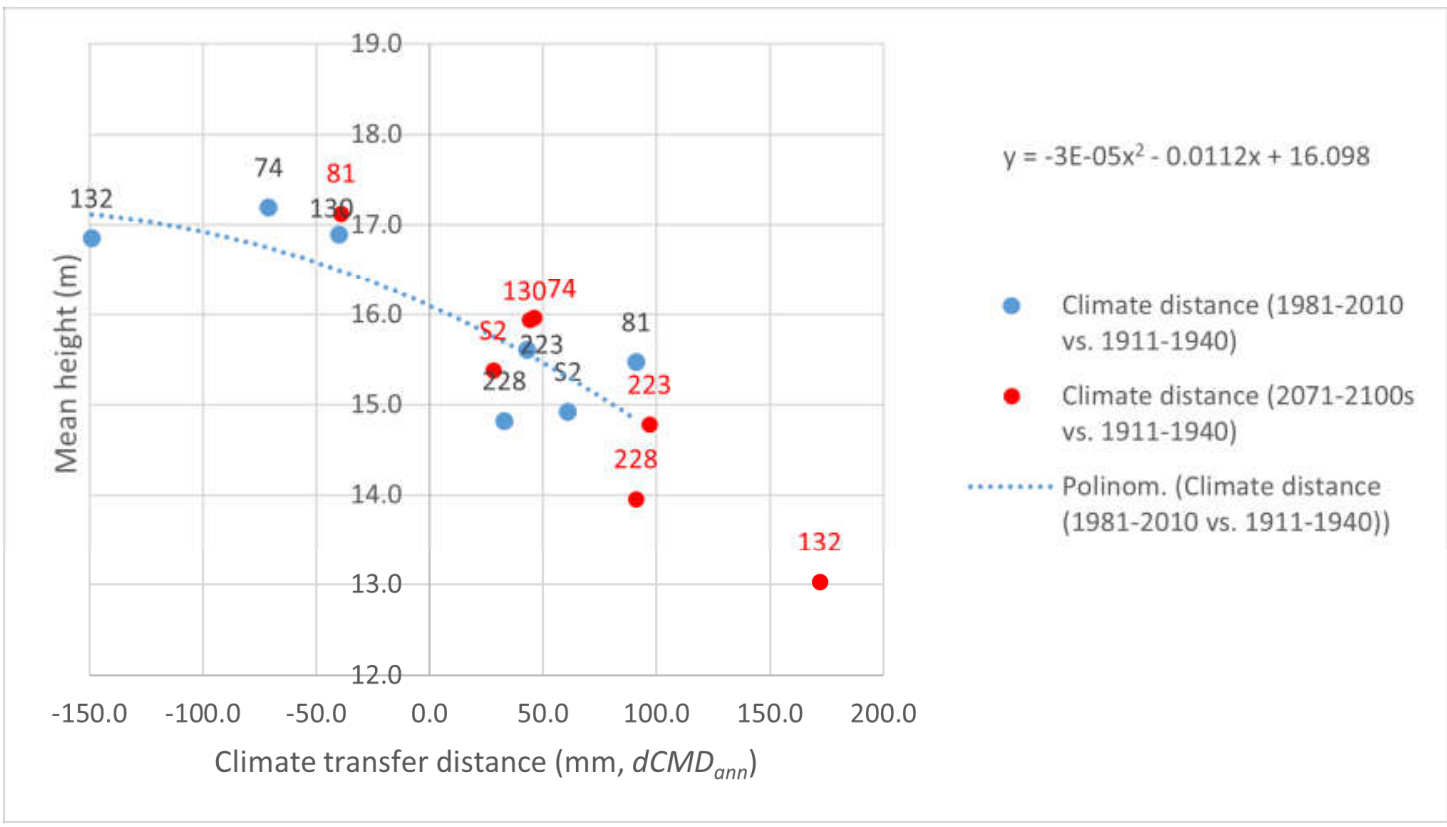

Figure 5. Comparison of current height at Písek and estimated future mean height response to climatic change of silver fir populations at their original location of provenance. Their performance is compared under two climatic transfer situations, current heights at the test site (data measured in 2015, blue dots) and projected heights at origin in the climate period 20712100 (derived from ClimateEU, pathway RCP8.5, red dots). The transfer equation for current vs past climate was extrapolated for future data. The horizontal axis shows climate distances in $d C M D$ units (mm precipitation deficit). For the sake of comparison, both current and future heights appear as the site index value for the age of 40 years, i.e., in 2015.

A further step is to estimate the population performance at their locations of origin, which is also calculated with the help of the equation for "current" vs. past data for silver fir, here using the climate projections for the individual sites of origin, run for the 20712100 period, using the database ClimateEU, pathway RCP8.5. While the climate projection for the future was the same for all populations in the Písek test, here every provenance has a different climate projection according to its original geographic location. (The differences in local site potential between the locations of provenance are not considered.) Comparing Figures 4 and 5, the scatter of projected points appears less drastic for the sites of origin (Figure 5), and their rank is different due to the change of the reference location.

The projections reveal the most vulnerable populations at their origins at the end of the century. The change of the position of provenance 81 (Vyšší Brod CZ) is notable, as it shows best the differentiation caused by individually projected climates. The highelevation population has responded with weak height in Písek, and its survival at the test site was the lowest. The projected climatic position at the original high-elevation site is, however, very suitable: $-39 \mathrm{~mm}$ moisture deficit (i.e., moisture surplus), and the expected response is the best-projected height: $17.13 \mathrm{~m}$ (Table A4). The silver fir provenance with the highest drought tolerance, the Bulgarian Borovec (132), will suffer from an extreme moisture deficit increase of $+172 \mathrm{~mm}$ at its origin. Its projected height response is the lowest with $13.0 \mathrm{~m}$. While it may survive in Písek, it will most likely go extinct in Bulgarian Borovec. Thus, the population will be more threatened by droughts at its original location than in the low-elevation site Písek towards the end of the century. Other populations with extreme moisture deficit are the Italian Regello and the Bosnian Sanski Most; both were among the weak performers also in the Písek trial. The two Czech low-elevation 
provenances of Nasavrky and Milevsko, as well as the Slovak Radvaň, will maintain their medium positions at their original location. In the case of the Balkan fir species, projections were calculated by the same equation for silver fir. Although their predicted relative drought change is above the assumed survival limit of $100 \mathrm{~mm}$ (for details, see the discussion), their current $d C M D_{a n n}$ values are so low that they will remain in the high moisture surplus zone at their origin, similar to the Písek trial location (Figure 3, Table A4).

\subsection{Comparison of Grand Fir Provenances in Trial 213, Zbiroh}

The trial contains 24 provenances of grand fir, among them 8 from Vancouver Island, Canada, three from the coastal belt north of Seattle, WA, and 16 sources from the Inland NW of the USA, representing higher altitude stands from the Cascades and the inland range in Idaho and Montana (Table 4). The shortcoming of this rather detailed collection of provenances is it contains no control populations of native silver fir in the trial; nonetheless, the within-species mean heights are worth comparing, in view of their possible use in East-Central Europe.

The Canadian sources all originate from low elevations of the eastern coast of Vancouver Island and receive high annual rainfall above $1000 \mathrm{~mm}$, but low summer precipitation (94-229 $\mathrm{mm}$ ). The three populations from coastal Washington (USA) enjoy somewhat less annual precipitation but also lower summer rainfall. The Cascade sources have similar rainfall ranges, while inland provenances in Idaho and Montana receive less annual precipitation $(684-933 \mathrm{~mm})$. Temperature conditions across the huge range from mild-coastal to continental-inland climates are relatively comparable in summer with means of $12.6-17.4^{\circ} \mathrm{C}$, while January mean temperatures show larger differences between coastal and inland locations (between 3.8 and $-6.0^{\circ} \mathrm{C}$ ). All climate data related to the past reference period 1911-1940 (Table 4).

The Kruskal-Wallis test results for mean heights quite clearly differentiate two main groups within the grand fir provenances. The first main group contains coastal populations from Vancouver Island (reg. numbers 12040 to 12047) and Puget Sound, Washington, USA (12002 to 12004). The latter populations display the best growth from all tested provenances. The second main group originates partly from higher elevations $(>700 \mathrm{~m})$ of the Washington and Oregon Cascades (12006 to 12020), with significantly weaker growth, while the populations from inland Idaho and Montana (12026 to 12031) form an overlapping heterogeneous group, representing highly variable ecological conditions and discontinuous ranges in the Rocky Mts. A significant outlier is Clearwater, Idaho (12038), a top grower (Figure A5).

In the trial of Zbiroh, "current" temperature conditions at the trial site (annual mean of $8.1^{\circ} \mathrm{C}$ and summer mean $17.0^{\circ} \mathrm{C}$ ) are within the data range of the sources from the American Northwest. The amount and distribution of rainfall is, however, notably different. "Current" annual precipitation amounts to only $595 \mathrm{~mm}$ in Zbiroh, but over one-third of these falls in the summer quarter $(241 \mathrm{~mm})$, producing a summer rainfall peak.

It is very illustrative to compare the climate charts of the weather stations at Zbiroh and Everett, a coastal station in the state of Washington, USA. The data for the charts were derived from [47], drawn by the ClimateChart application (climatecharts.net). Figures 6 and 7 display the diametrical difference of the climate of Central-Southeast Europe versus the mild, oceanic "Sub-Mediterranean type" climate along the inland coast of Washington State (Puget Sound). At the test site, most grand fir provenances experienced a drastic decrease in their annual precipitation with the exception of inland sources, where the decrease was less (Table 4). The mean summer rainfall at Zbiroh, however, was higher. These differences caused all provenances to experience a wetter and warmer summer climate at the test site than at origin (Figure 8, Figure A2a,b). Adapted to relatively dry summers, grand fir populations did not suffer from summer drought stress at Zbiroh for obvious reasons (Figure 8). 


\section{Zbiroh, Czech Republic}

49.951N, 13.791E | Elevation: 503 m | Climate Class: Cfb | Years: 1961-1990

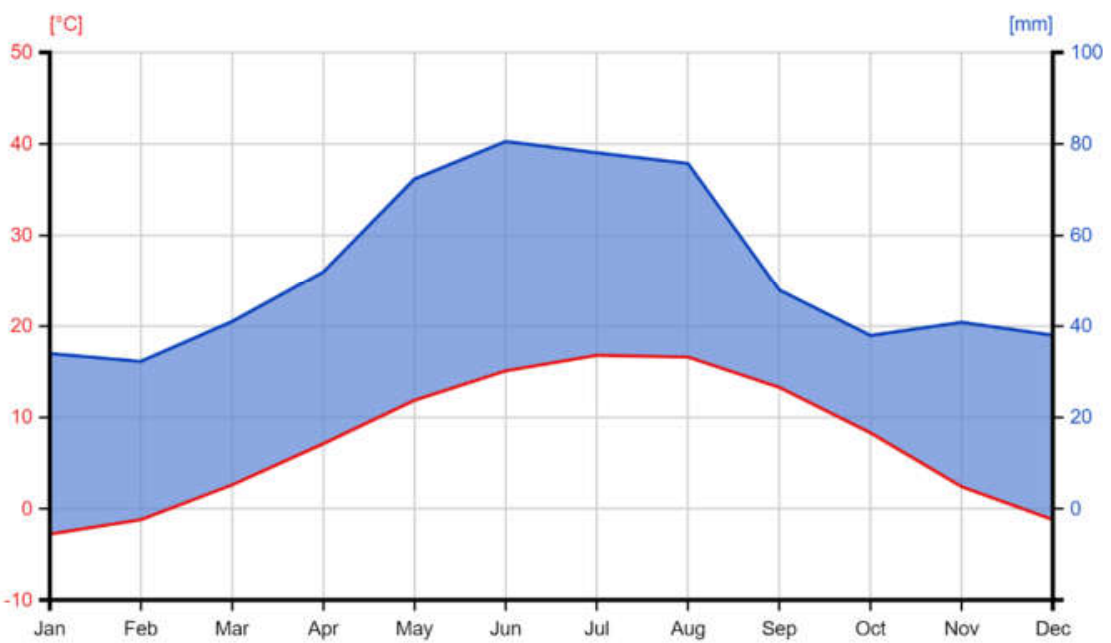

Figure 6. Climate chart of the trial Zbiroh (mean annual data for 1961-1990: temperature $7.2{ }^{\circ} \mathrm{C}$; precipitation: $586 \mathrm{~mm}$ ). Note the quantity and seasonal distribution of precipitation with a summer maximum.

\section{Everett, Washington, United States} 48.1N, 122.3W | Elevation: 78 m | Climate Class: Cfb | Years: 1961-1990

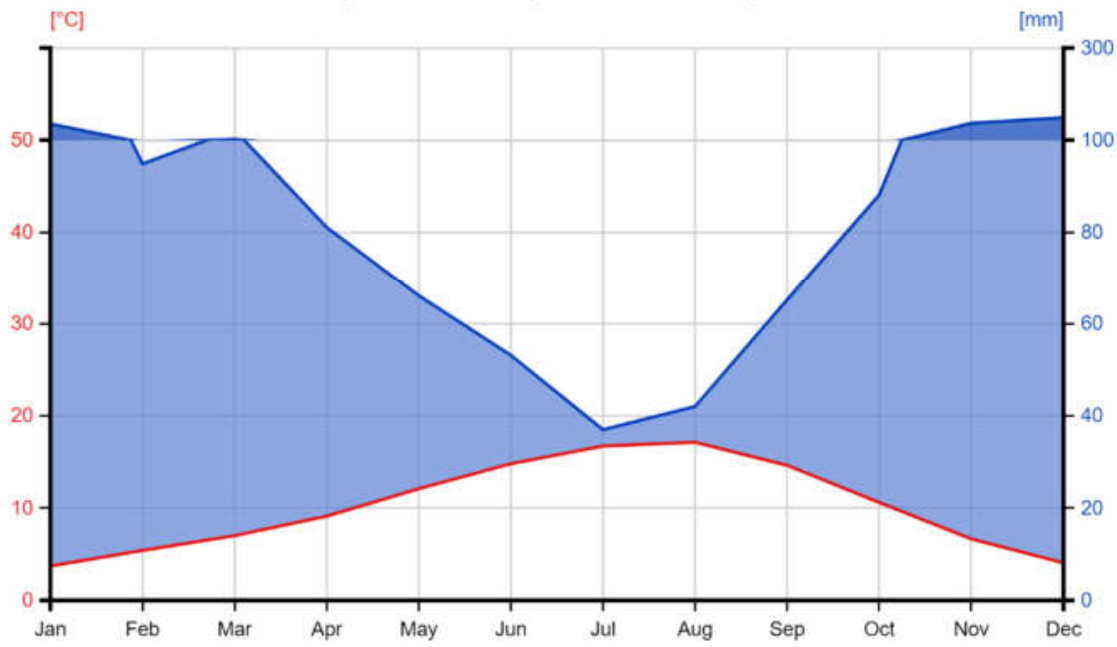

Figure 7. Climate chart of the weather station Everett, Washington (mean annual data for 19611990: temperature $10.3^{\circ} \mathrm{C}$; precipitation: $950 \mathrm{~mm}$ ). Note the "Sub-Mediterranean type" distribution of rainfall with minimum precipitation in July.

Thus, the high resilience potential and better growth of grand fir appears to be linked to their adaptation to the high summer aridity at their origin. This result obtained under subcontinental climate conditions contrasts the opinion that at the interspecific level, the precipitation in the wettest month or in the wettest quarter at the location of origin is the best predictor for summer drought response [35]. 


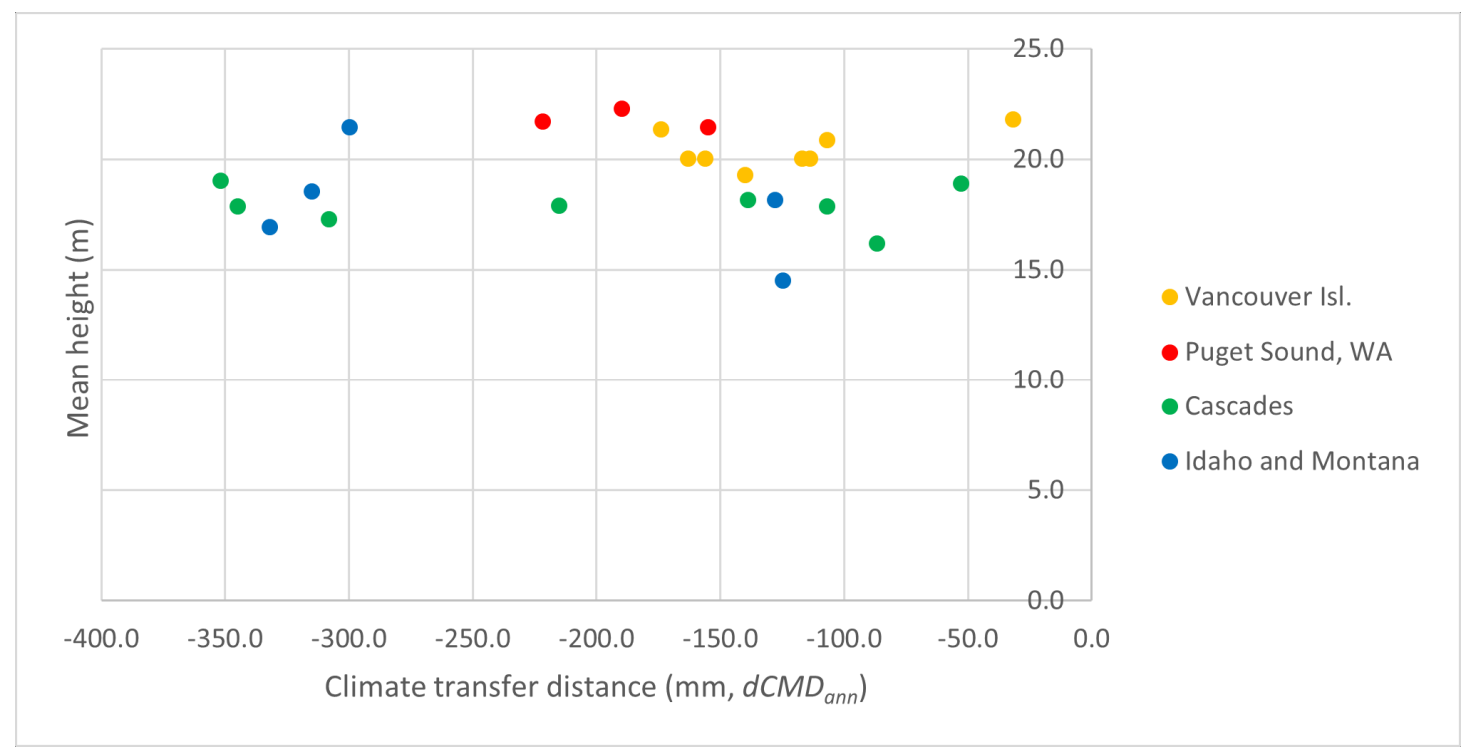

Figure 8. Mean height response of grand fir provenances to climate transfer distance (current vs past) expressed in annual climatic moisture deficit (mm precipitation deficit $d C M D_{a n n}$ ), in the trial Zbiroh. Colors indicate origin of populations (see also Figure A2a,b for climatic distances, expressed in temperature and precipitation changes). Note the differentiation by provenance groups.

The distribution of height data across the ecological space of tested populations indicates no correlation with the amount of moisture surplus in any of the provenance groups. Neither the drastic increase of summer temperature (up to $3.9^{\circ} \mathrm{C}$, for Santiam Summit USA/OR) nor the increase of summer precipitation (up to $185 \mathrm{~mm}$, for Eagle Creek, WA) have produced a significant trend change of heights (Table 4, Figure A2), which indicates a considerable resilience of the species to the change of moisture supply. A direct comparison with silver fir was not possible in these trials, but the top performance of grand fir provenances in other European trials [48] corroborates the extraordinary growth and resilience of the species. One reason for the superiority of the species across Central Europe is most probably the wetter summer climate when compared to the original sites.

The projection of the phenotypic response of the populations at lower elevations in the Czech Republic (Písek) for the climate period 2071-2100 was also attempted for grand fir. Most populations indicated moisture surplus conditions at the test site; therefore, it may be assumed that grand fir provenances will tolerate the projected future climate, especially at higher elevations in East-Central Europe.

\subsection{Comparison of Noble Fir Provenances in the Trial 219, Dražičky}

The six tested noble fir provenances originate from ecologically rather similar, medium elevations (900-1065 m a.s.l.) of the Central-Southern Cascades (Table 5). Their climatic differentiation is moderate; the annual and summer mean temperature difference between northern and southern sources is less than $2{ }^{\circ} \mathrm{C}$. Precipitation conditions vary between 1800 and $2800 \mathrm{~mm}$ annually, out of which, however, only 90-200 $\mathrm{mm}$ falls in the summer quarter, which is less than the summer mean at the trial site $(229 \mathrm{~mm})$. One silver fir and two grand fir populations were added for comparison. The main climatic effect of transfer for the two American species was the markedly lower annual precipitation; however, rainfall was somewhat higher in the summer quarter (by 20-140 $\mathrm{mm}$ ) than at the original locations (Table 5, Figure 7, 9 and A3a,b). 


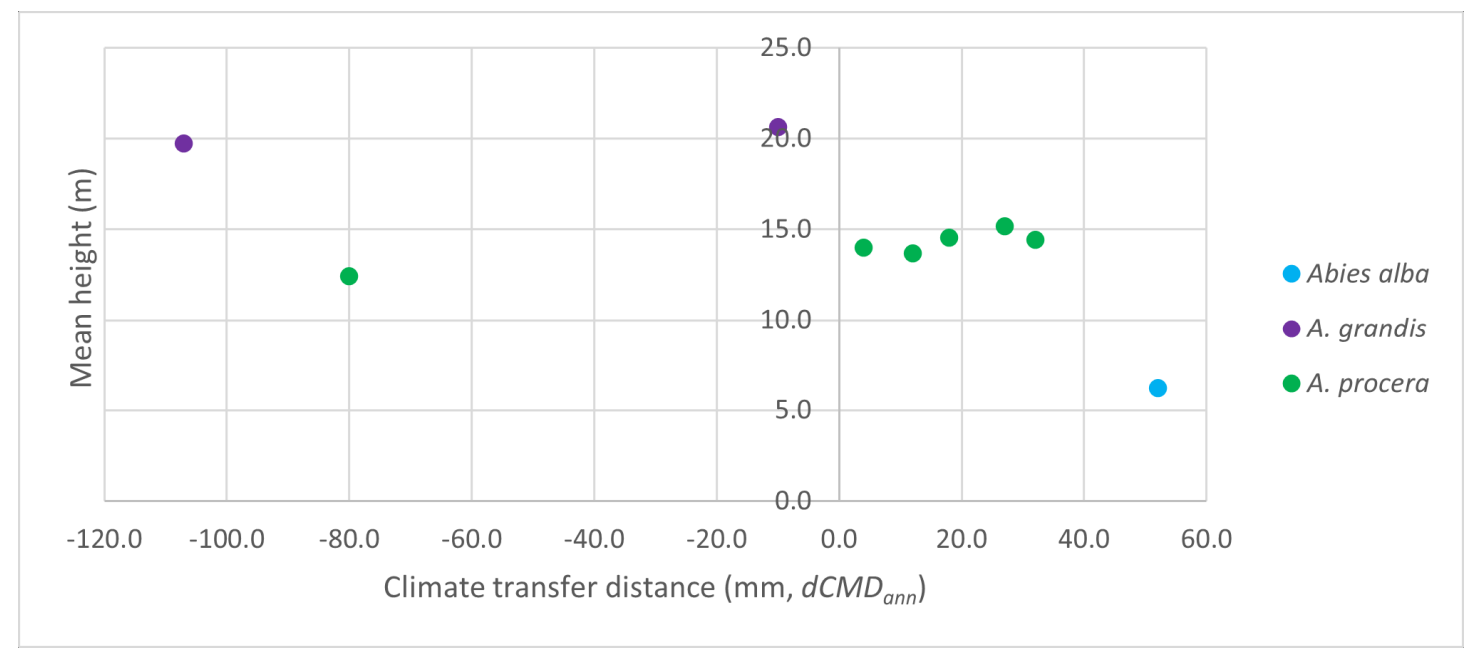

Figure 9. Mean height response of noble fir provenances to climate transfer distance (current vs past) expressed in annual climatic moisture deficit ( $\mathrm{mm}$ precipitation deficit $d C M D_{a n n}$ ), in the trial Dražičky (see also Figure A3a,b for distances expressed in temperature and precipitation).

Noble fir has shown a low sensitivity to summer aridity conditions, similar to grand fir, and tolerated a drastic decline of annual precipitation (over $1500 \mathrm{~mm} /$ year less), while summer precipitation was higher than adapted to at the original location. The KruskalWallis test did not separate the majority of noble fir populations, only the southernmost ones (13004 and 13006, see Table 5 and Figure A6). The provenances have shown minor differentiation of height at age 32, related to climatic transfer distance, which did not change even in the case of the extreme provenance Stevens Pass, WA (13021). This population has shown the highest resilience to changing climatic conditions; it tolerated a five-degree increase of summer and annual temperature with no decline in height. With the exception of one provenance (13004 Mary's Peak, OR), all displayed moderate moisture deficits, with no effect on growth (Table 5). The projection of future climatic moisture deficits (calculated the same way as before) for the climate period 2071-2100 parallels the results of grand fir. Future moisture deficit values may reach $130 \mathrm{~mm}$; thus, some populations may show a significant decline in the last third of this century. Judged on its performance, noble fir does not qualify for introduction.

Buck Creek and Ellensberg, the two low-elevation provenances of grand fir serving for comparison, have shown superior growth responses, similar to the results of the populations in the Zbiroh trial. The weaker performance of the noble fir provenances is statistically confirmed (Figure A6).

Adršpach, the Czech silver fir standard in the trial Dražičky, is certainly not representative of high-altitude Czech provenances and its growth is unsuitable for a realistic comparison. The extremely poor mean height indicates the harsh site conditions at its origin (Table 5 shows for the population the lowest January mean temperature, $-5,1$ $\left.{ }^{\circ} \mathrm{C}\right)$. Its slower growth has probably declined further due to the competition of neighboring plots, indicated also by its worst survival among all provenances in the trial.

\section{Discussion}

\subsection{Adaptive Differentiation in Drought Tolerance}

The Písek trial shows a significant adaptive differentiation for silver fir indicated by the clear relation between climate transfer distance (relative drought stress) and mean height of provenances. The regression depicts an exponential decline of height growth with increasing relative drought stress, determined by the past drought conditions at the site of origin. The regression is similar to unilateral climate transfer distance regressions calculated in provenance tests of other species (e.g., beech: [49]; sessile oak: [40]). Earlier 
findings [34,35] indicated that silver fir provenances display high within-species differentiation regarding adaptive stress response when compared to other species are upheld by these results.

In some studies, intraspecific differentiation in silver fir is interpreted concurrently with adaptive selection as a result of tradeoff effects [33,50] or linked to alternate biogeographic histories [8,36,37,51]. Our results cannot ascertain either opinion, supporting that the growth response to warming/drying climate scenarios seems to be determined compellingly by adaptation to past climates. The correlation of responses with climates of the recent past suggests that the differentiation may have evolved in a shorter evolutionary period than usually assumed and might be enhanced by epigenetics. The maintenance of the differentiation has been observed until advanced age. The generally superior growth and drought resilience of grand fir populations found also in other lowelevation tests [52], is attributed to the summer rain peak in Central Europe, which causes less summer aridity stress than at the populations' origins.

The existence of tradeoff effects, i.e., a negative correlation between drought tolerance and inherent height growth, may be assumed for the Balkan fir species ( $A$. borisii-regis and A. cephalonica). Their weaker growth may be explained by higher drought tolerance at the expense of compromised photosynthetic capacity, especially close to the rear/xeric limits $[33,35,50,53]$.

\subsection{Projected Adaptive Response of Silver Fir to Future Climatic Challenges}

Until the end of the century, the running of the ClimateEU model under pathway RCP8.5 calculates a drastic annual mean temperature increase of ca. $4.5^{\circ} \mathrm{C}$ at all three sites, while the increase of precipitation is moderate (Table A2). Consequently, the local climatic moisture deficit may increase, reaching the highest value of $315 \mathrm{~mm}$ at Písek (current value: $213 \mathrm{~mm})$. The calculated future climatic transfer distances $\left(d C M D_{a n n}\right)$ and the projected heights of silver fir provenances at Písek and their origins (Figures 4 and 5) may provide estimations for their survival and the chances for transfer (assisted migration) for silver fir.

Whether the climate projected for the period 2071-2100 surpasses the limit of drought tolerance and survival of individual silver fir populations cannot be judged directly from their present growth in the trial Písek due to the lack of reliable mortality data. Bearing in mind the within-species differentiation in drought tolerance, a species-specific uniform tolerance limit for climatic moisture deficit of transferred populations cannot be set. The relatively high values of past moisture deficit indicate that the inherited drought resilience of populations is not fully challenged by the present test conditions.

An indirect approach for estimating the tolerance limit was attempted by selecting sites for comparison, artificially regenerated with silver fir, which were identified as actual climatic limits of the species in the subcontinental climate (Table 6). In the Czech Republic, a specific experiment, planted in 1975 in Jíloviště/Cukrák (FGMRI, trial No. 211) right at the assumed climatic limit of silver fir in the hornbeam-oak mixed forest zone, was selected [54]. Similar sites were identified in Hungary (Sopron 85 K, planted in 1900, Figure 10) and Slovenia ( $\mathrm{Zg}$. Gruskovje). The low-elevation Slovenian site is comparatively mild, it turned out to be of natural origin at the low-elevation SE limit of the species. The artificially established Czech and Hungarian locations show moisture supply conditions at the dry, subcontinental limits of the species (Table 6). Their "current" conditions indicate annual moisture deficits of 296 and $276 \mathrm{~mm}$, respectively, projected to increase to 389 and $393 \mathrm{~mm}$ by the end of the century. These values qualify the current annual moisture deficit of the test site Písek as quite distant from the xeric limit conditions for artificially regenerated silver fir. 


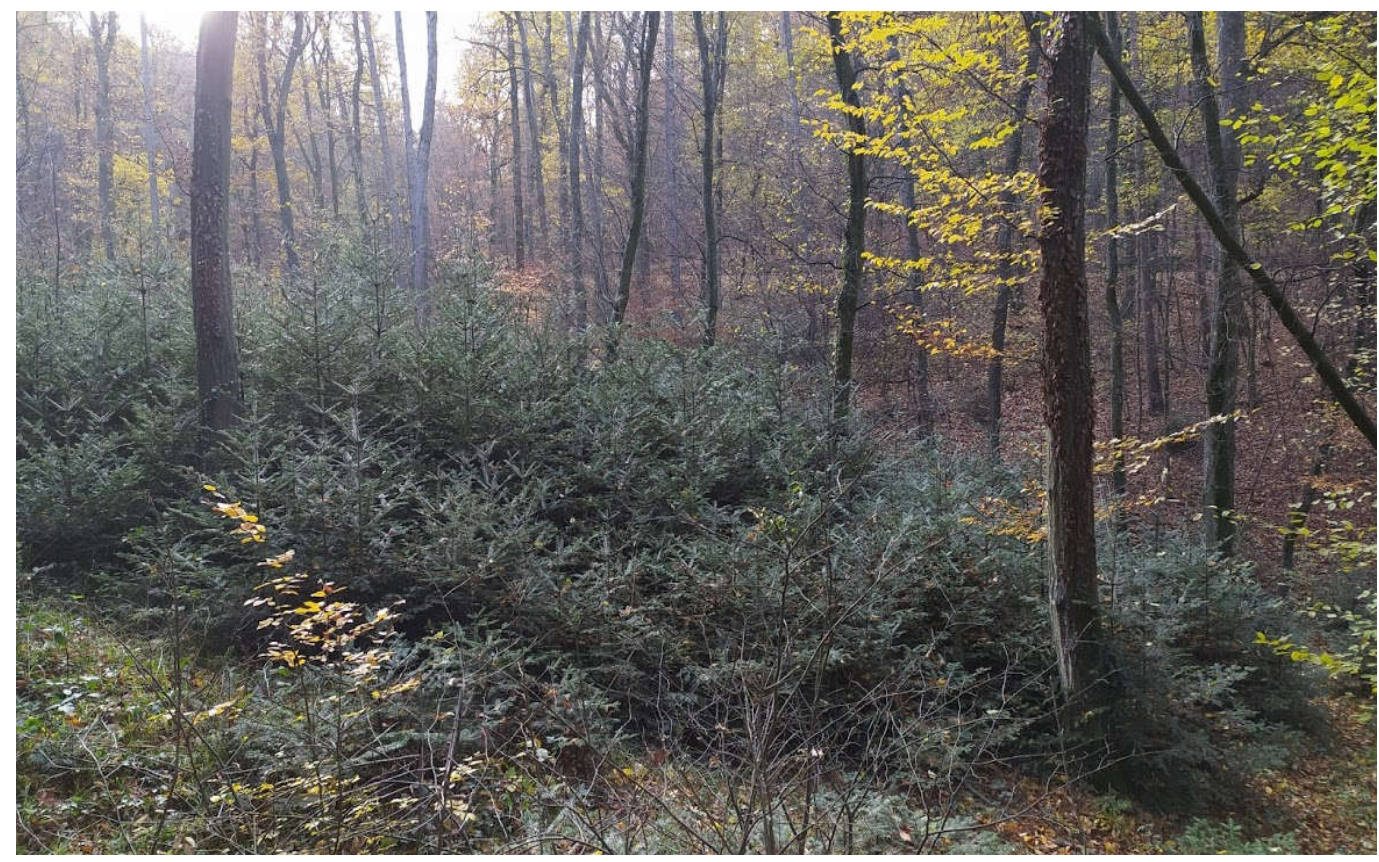

Figure 10. Vigorous natural regeneration of silver fir in a regerenation cut, in the mixed sessile oak/hornbeam forest zone in Sopron, Hungary, at the xeric limits of artificially re-introduced silver fir (elevation $340 \mathrm{~m}$, current climatic moisture deficit: $276 \mathrm{~mm}$, further details in the text and Table 6; photo: P. Balázs).

Primarily the level of relative drought $(d C W D a n n)$ is assumed to decide on population survival. A basis for the rough estimation of the relative drought tolerance limit might be the difference between the "artificial" (Jíloviště) and the "natural" (Písek) moisture deficit values, 296 vs. $213 \mathrm{~mm}$, respectively (see Table 6 and Table A2). The difference of $83 \mathrm{~mm}$ comes close to the observed maximum of relative moisture deficits in Písek. The highest value of $91 \mathrm{~mm}$ relative deficit was determined for the Czech provenance 81, Vyšší Brod. Its apparently low survival (10\%, Table 3) may indicate declining adaptation to changed conditions. Hereafter, an arbitrary value of $100 \mathrm{~mm}$ relative moisture deficit is assumed for a limit of relative drought tolerance for silver fir at subcontinental zonal sites. (Zonal refers here to rain-fed sites with sufficient water holding capacity of the soil.)

Table 6. Past, „,current" and projected future climate data for selected locations in the Czech Republic, Hungary and Slovenia considered as xeric/rear limits of silver fir distribution at low elevations in Central-Eastern Europe (source of climate data: ClimateEU, projected pathway RCP8.5; for comparison with test site conditions see also Table A2).

\begin{tabular}{ccccc}
\hline $\begin{array}{c}\text { Location, Elevation }(\mathbf{m}), \\
\text { Geogr. Coordinates } \\
\text { (Decimal Degrees) }\end{array}$ & Climate Period & $\begin{array}{c}\text { Annual Mean } \\
\text { Temperature }\left({ }^{\circ} \mathbf{C}\right)\end{array}$ & $\begin{array}{c}\text { Anual Mean } \\
\text { Precipitation }(\mathbf{m m})\end{array}$ & $\begin{array}{c}\text { Annual } \\
\text { CMD (mm) }\end{array}$ \\
\hline Jíloviště CZ, Trial No.211 & $1911-1940$ & 9 & 416 & 331 \\
310m & $1981-2010$ & 9.2 & 477 & 296 \\
Lat. 49.944, Long. 14.356 & $2070-2100$ & 13.5 & 522 & 389 \\
\hline Sopron HU, comp.85 K. & $1911-1940$ & 9.3 & 539 & 312 \\
340m & $1981-2010$ & 9.5 & 623 & 276 \\
Lat. 47.667, Long. 16.563 & $2070-2100$ & 14.1 & 661 & 393 \\
\hline Zgornje Gruskovje SI, & $1911-1940$ & 9.8 & 831 & 202 \\
325m & $1981-2010$ & 10 & 965 & 172 \\
Lat. 46.272, Long. 15.860 & $2070-2100$ & 14.6 & 978 & 271 \\
\hline
\end{tabular}

The relative moisture deficit differences $\left(d C M D_{a n n}\right)$ projected for the transferred populations in the period 2071-2100 in Písek are shown in Figure 4 and Table A3. It is evident that high-elevation provenances $(81,223,228$ and S2) are exposed to relative drought values above the set limit. While these populations survived and performed 
sufficiently well in the current climate, this could change by the end of the century, and they may go extinct. On the contrary, the high-elevation Bulgarian provenance (132, Borovec), adapted to extreme drought stress, may survive at the low-elevation Písek site (see also the results chapter). Hence, it is expected that low-elevation populations may survive the climate of Písek until the end of the century, but some of the high-elevation populations will be lost. Their transfer to a low-elevation site as an "adaptive measure" would be pointless and illogical.

Of course, the survival of populations at their original locations and the prospects for assisted transfer is of primary interest for the projected future. Figure 5 shows the expected relative drought values for the end of the century at the original locations, i.e., at their provenance. It is self-evident that the survival of populations is more probable at their original sites than at Písek. Only the extremely high relative drought value of Bulgarian provenance 132, Borovec, indicates probable local extinction at the end of the century. Other, partly low-elevation populations will be stressed, but will probably survive. Favorable climates are projected for two provenances from high elevations (74 Vyšší Brod CZ and S2 Radvaň SK); the site conditions there may even improve due to projected higher rainfall. Calculating the relative drought values based on their current climate, the future survival of populations introduced to sites outside the natural range limits of silver fir (such as Jíloviště and Sopron, Table 6) appears questionable.

The individual differentiation between provenances due to diverging climate projections is apparent when comparing projected survivals at the test site and their origin. The population 132, Borovec BG is an extreme example, which may go locally extinct at its origin, but survives in the climate of the low-elevation site Písek. Conversely, the Czech and Slovak high-elevation provenances will survive at their origin but may be lost in the trial Písek. The location-bound, individual projections may provide concrete guidance for selecting reproductive material for future climates and for identifying climatically threatened valuable populations for evacuation.

Some of the conclusions contradict generally accepted opinions. The advantage of local provenances compared to non-locals is generally derived from transfer functions based on common garden results. However, if response norms are available for individual populations, the assumed superiority of artificially regenerated (transferred) local populations may often be questioned $[40,55,56]$. Here, this was also found for silver fir. In view of the speed of climatic changes, the superiority of local provenances cannot be taken for granted for the future; growth and survival will depend on projected local climate conditions. Similarly, the experience that southern and eastern silver fir provenances respond with the best growth and resilience, as found already in the first provenance test $[27,30]$ and confirmed in later trials as well $[8,29,57]$, is not generally valid. Further, the negative correlation between drought tolerance and inherent height growth has led to the conclusion that superior growth is generally linked with lower drought tolerance. Although this trade-off effect exists across a wide range of temperate and boreal tree species $[14,40,56]$, our results did not ascertain this for silver fir, and a recent, very detailed experimental series of a silver fir [57] gave the same result. The projections also reveal that transfers may safeguard the survival of otherwise threatened populations. These conclusions support that generalized opinions on the expected performance of populations should be refined by a detailed inspection of past and future climatic projections. The inherent adaptive capacity, i.e., the resilience of the populations, may surpass the often implicitly assumed "perfect" adaptation under undisturbed, natural conditions. To project future species distributions without taking into consideration the adaptive capacity of populations may therefore underestimate the climatic resilience of species $[3,14]$.

\subsection{Limitations of the Study Results}

None of the investigated provenance trials is perfect regarding the representativeness of the set of provenances, and the design of the experiment. Similarly, the applied datasets 
for projecting past and future climates represent the present level of knowledge. Hence, the results reflect the limitations of the investigated material and the applied methods. The results are based on the input provided by the selected climate variable and the climate projections, which cannot forecast unforeseen geophysical, biological (and socioeconomic) events. Therefore, it remains a model based on real-time data that anticipates validation via coming episodes of terrestrial evolution.

The confidence of evaluating responses of species and populations was determined by the current condition of the tests. Owing to their advanced age, the plot sizes and the remaining number of trees per plot were far from optimal, which made statistical evaluations nearly impracticable (see details of variance statistics in Figures A7-A9). An analysis of survival/mortality was not performed, due to missing records on intermediate thinnings. Lacking reliable data on current mortality was also the reason why the climate extremes during the long maintenance period of the tests were not analyzed; these details would not have contributed much to the planned aim of the paper, which was the transparent presentation of the new results that these aged experiments were able to provide. The manifold methodical and practical limitations of the three trials were taken as a challenge to extort useful conclusions from the dataset. The authors are confident that the results justify the compromises, which had to be made.

\section{Conclusions}

The projections of the study may affect the future management of silver fir in EastCentral Europe. Careful management supporting the successive adaptation of silver fir may be assumed as sufficient until the end of the century, especially in less-threatened higher elevations. High-elevation populations may even enjoy more suitable growth conditions. In other instances, particularly close to the xeric limits where enhancement of ecosystem resilience is required, artificial regeneration and assisted migration are options to preserve or restore silver fir occurrences. The introduction of provenances of the closely related Balkan species A. cephalonica and A. borisii-regis is a realistic choice at exposed lower elevations. The geographically and climatically distant Mediterranean fir species cannot be alternatives for silver fir [20,35]. The breeding for resilience proposed by some authors is only a theoretical possibility, considering the time necessitated.

The cautious use of grand fir in mountain forests is also conceivable (e.g., in Poland: [58]). Regarding health risks, investigation in the trials Dražičky and Zbiroh were inconclusive; however, both fungus and insect damage was reported in other grand fir stands in the Czech Republic, apparently triggered by recent extreme droughts [20]. Bearing in mind the technical and economic efforts needed, as well as plant health risks of non-native plant material [59], the introduction of grand fir will probably remain on the level of color splashes.

When choosing reproductive material for regeneration and transfer, resilience and tolerance to extremes must have priority over growth and yield traits. Selecting preadapted populations for transfer, the genetic risks using material of isolated, small occurrences should be considered, as well as the fact that transferred reproductive material may be at a competitive disadvantage in the initial years compared to local populations. To reduce risks of transfers and introductions, the gathering of available information, the field monitoring of extreme events [35,60,61], and antagonist organisms of any kind should not be ignored.

Methodically, the study presents a new approach to interpret experimental data in the context of projected climate scenarios. The introduction of relative drought, based on climatic moisture deficit change explains current responses of transferred tree populations and may predict their future performance and survival. Our results underscore the potential of provenance tests to provide practice-oriented information in order to mitigate the effects of a rapidly changing climatic environment. They may provide less dramatic and more detailed projections of future performance, counting with the resilience of populations, which cannot be forecasted by inventory-type, in-situ field analyses (e.g., 
[62]). The presented method, as well as the lengthy time needed to obtain reliable results from new experiments, may promote the reassessment of existing provenance tests and the reanalysis of their data supported by improved global and regional climate databases.

Author Contributions: Conceptualization, C.M. and J.F.; formal analysis, J.D., P.B. and M.V.; investigation, F.B., J.Č. and M.F.; writing-original draft preparation, C.M.; writing-review \& editing, C.M., J.F. and G.B. visualization, P.B.; project administration, J.F., C.M.; funding acquisition, J.F., C.M. All authors have read and agreed to the published version of the manuscript.

Funding: Research work in the Czech Republic was supported by the fund MZE-RO0118, provided by the Ministry of Agriculture.

Institutional Review Board Statement: Not applicable.

Informed Consent Statement: Not applicable.

Data Availability Statement: Not applicable.

Acknowledgments: Authors are grateful to all members of FGMRI Department of Biology and Forest Tree Breeding research team, involved in field works and data processing activities connected with the provenance trials. Csaba Mátyás was supported in Hungary by the joint national-EU research project “VKSZ_12-1-2013-0034-Agrárklima.2”. Gregor Božič was supported by the Slovenian Research Agency (P4-0107) and the national research projects V4-1818, V4-1819 cofinanced by the Ministry of Agriculture, Forestry and Food. Special thanks are expressed to Tongli Wang (UBC Vancouver, Canada) for downscaling climate datasets for locations analyzed in the study, to Raphael Klumpp (Fed. Forest and Landscape Research Inst., Vienna, Austria) providing data on the provenance test in Knödelhütte, and to Anikó Kóczán-Horváth (University Sopron, Hungary) for statistical analyses. The careful, thorough linguistic correction of the manuscript by Frank Berger (University Sopron, Hungary) and the helpful comments of anonymous reviewers are gratefully acknowledged.

Conflicts of Interest: The authors declare no conflict of interest. The funders had no role in the design of the study; in the collection, analyses, or interpretation of data; in the writing of the manuscript, or in the decision to publish the results.

\section{Appendix A}

Additional Climate Data of Test Sites and Provenances

Table A1. Origin of climate data used for test sites.

\begin{tabular}{lcccc}
\hline Test Site Name & $\begin{array}{c}\text { Meteorological } \\
\text { Station Name }\end{array}$ & $\begin{array}{c}\text { Altitude of } \\
\text { Station }\end{array}$ & $\begin{array}{c}\text { Distance from } \\
\text { Site } \mathbf{( k m )}\end{array}$ & $\begin{array}{c}\text { Altitude of Site } \\
\text { (m a.s.l.) }\end{array}$ \\
\hline Písek & Vráž & 433 & 19 & 395 \\
Zbiroh & Zbiroh & 480 & 11 & $450-460$ \\
Dražičky & Tábor & 461 & 7 & 485 \\
\hline
\end{tabular}


Table A2. Past, ,"current” and projected future climate data for the three trial sites in the Czech Republic (source of climate data: ClimateEU; projected pathway RCP8.5).

\begin{tabular}{cccccccc}
\hline $\begin{array}{c}\text { Location } \\
\text { Elevation (m) } \\
\text { Coordinates }\end{array}$ & Climate Period & $\begin{array}{c}\text { Mean Temperature } \\
\left({ }^{\circ} \mathbf{C}\right)\end{array}$ & $\begin{array}{c}\text { Mean Precipitation } \\
(\mathbf{m m})\end{array}$ & \multicolumn{2}{c}{$\begin{array}{c}\text { CMD } \\
(\mathbf{m m})\end{array}$} \\
& & Annual & Summer & Annual & Summer & Annual & Summer \\
\hline Písek. CZ Trial No.64 & $1911-1940$ & 8.7 & 17.6 & 548 & 205 & 273 & 150 \\
395m & $1981-2010^{*}$ & $8.1^{*}$ & $17.2^{*}$ & $570^{*}$ & $229^{*}$ & 213 & 137 \\
Lat. 49.27 & $2040-2070$ & 11.4 & 20.9 & 709 & 246 & 234 & 154 \\
Long. 14.33 & $2070-2100$ & 13.2 & 23.2 & 691 & 222 & 315 & 211 \\
\hline Zbiroh. CZ Trial No.213 & $1911-1940$ & 7.7 & 16.4 & 533 & 191 & 234 & 134 \\
$456 m$ & $1981-2010^{*}$ & $8.1^{*}$ & $17^{*}$ & $595^{*}$ & $241^{*}$ & 179 & 120 \\
Lat. 49.79 & $2040-2070$ & 10.4 & 19.7 & 689 & 230 & 199 & 136 \\
Long. 13.64 & $2070-2100$ & 12.1 & 22 & 673 & 209 & 274 & 189 \\
\hline Dražičky. CZ Trial No. 219 & $1911-1940$ & 8.1 & 16.9 & 539 & 206 & 250 & 137 \\
$488 m$ & $1981-2010^{*}$ & $8.1^{*}$ & $17.3^{*}$ & $592^{*}$ & $229^{*}$ & 189 & 122 \\
Lat. 49.39 & $2040-2070$ & 10.9 & 20.3 & 696 & 247 & 209 & 140 \\
Long. 14.59 & $2070-2100$ & 12.7 & 22.6 & 678 & 224 & 288 & 196 \\
\hline
\end{tabular}

${ }^{*}$ Respectively the current testing period, CZ met. Data.

Table A3. Climate parameters and heights of silver and Balkan firs in past, current and projected climates and heights in the Písek trial (see also Figure 4).

\begin{tabular}{|c|c|c|c|c|c|c|c|c|c|c|}
\hline \multicolumn{3}{|c|}{ Populations of the Provenance Trial 64 Písek, CZ } & \multicolumn{3}{|c|}{$\begin{array}{c}\text { Past Climate at Origin } \\
(1911-1940)\end{array}$} & \multirow{2}{*}{$\begin{array}{c}\text { Current } \\
\text { Climate } \\
\text { Mean } \\
\text { Height } \\
\text { (Year } \\
\text { 2015) (m) }\end{array}$} & \multicolumn{4}{|c|}{ Future Climate (2071-2100) } \\
\hline $\begin{array}{cc} & \text { Abies Species } \\
\text { Nr. } & \text { Name }\end{array}$ & Provenance Name & $\begin{array}{l}\text { Alt. } \\
\text { (m) }\end{array}$ & $\begin{array}{l}\text { Ann. } \\
\text { Mean } \\
\text { Temp. } \\
\left({ }^{\circ} \mathrm{C}\right)\end{array}$ & $\begin{array}{l}\text { Ann. } \\
\text { Mean } \\
\text { Prec. } \\
(\mathrm{mm})\end{array}$ & $\begin{array}{l}\text { Ann. } \\
C M D \\
(\mathrm{~mm})\end{array}$ & & $\begin{array}{c}\text { Temp. } \\
\text { Annual } \\
\text { Change } \\
\left({ }^{\circ} \mathrm{C}\right)\end{array}$ & $\begin{array}{c}\text { Prec. } \\
\text { Annual } \\
\text { Change } \\
(\mathrm{mm})\end{array}$ & $\begin{array}{c}\text { Ann. } \\
d C M D \\
(\mathrm{~mm})\end{array}$ & $\begin{array}{c}\text { Proj. } \\
\text { Mean } \\
\text { Height } \\
(\mathrm{m}) * * *\end{array}$ \\
\hline 74 A. alba & Milevsko, Klučenice CZ & 410 & 8.4 & 492 & 284 & 17.19 & 4.8 & 199 & 31 & 16.17 \\
\hline 81 A. alba & Vyšší Brod, Vítkův Kámen CZ & 900 & 5.9 & 854 & 122 & 15.47 & 7.3 & -163 & 193 & 13.46 \\
\hline 109 A. cephalonica & Centr. Peloponnese, Vytina GR & 1250 & 10.9 & 794 & 573 & 14.19 & 2.3 & -103 & -258 & 14.94 \\
\hline 130 A. alba & Nasavrky, Podhůra CZ & 370 & 8.2 & 487 & 253 & 16.89 & 5.0 & 204 & 62 & 15.68 \\
\hline 132 A. alba & Rilskije gory, Borovec BG* & 1200 & 7.3 & 515 & 362 & 16.85 & 5.9 & 176 & -47 & 16.31 \\
\hline 136 A. cephalonica & Peloponnese, Vytina GR & 1010 & 12.2 & 753 & 626 & 14.34 & 1.0 & -62 & -311 & 15.41 \\
\hline 137 A. borisii-regis & Mt. Pindos, Pertuli GR* & 1200 & 9.6 & 727 & 503 & 14.59 & 3.6 & -36 & -188 & 14.91 \\
\hline 223 A. alba & Sanski Most $\mathrm{BH}^{*}$ & 1050 & 6.9 & 943 & 170 & 15.61 & 6.3 & -252 & 145 & 13.89 \\
\hline 228 A. alba & Regello, Vallombrosa IT* & 1010 & 9.5 & 967 & 180 & 14.82 & 3.7 & -276 & 135 & 13.16 \\
\hline$\underline{\mathrm{S} 2}$ A. alba & Banská Bystrica, Radvaň SK* & 780 & 6.4 & 759 & 152 & 14.92 & 6.8 & -68 & 163 & 13.09 \\
\hline \multicolumn{2}{|c|}{ Data and current climate of the test site ${ }^{* *}$} & 395 & 8.1 & 570 & 213 & 15.49 & & & & \\
\hline \multicolumn{2}{|c|}{ Future climate of the test site (2071-2100, RCP 8.5) } & 395 & 13.2 & 691 & 315 & & & & & \\
\hline
\end{tabular}


Table A4. Climate parameters of silver and Balkan firs in the past, current heights (in Písek) and projected climatic changes (related to the past) and projected (Proj.) heights at their original location of provenance (see also Figure 5).

\begin{tabular}{|c|c|c|c|c|c|c|c|c|c|c|c|}
\hline \multicolumn{4}{|c|}{ Populations of the Provenance Trial 64 Písek, CZ } & \multicolumn{3}{|c|}{$\begin{array}{c}\text { Past Climate at Origin } \\
(1911-1940)\end{array}$} & \multirow{2}{*}{$\begin{array}{c}\text { Current } \\
\text { Climate } \\
\text { Mean } \\
\text { Height } \\
\text { (Year } \\
\text { 2015) (m) }\end{array}$} & \multicolumn{4}{|c|}{ Future Climate (2071-2100) } \\
\hline Nr. & $\begin{array}{c}\text { Abies Species } \\
\text { Name }\end{array}$ & Provenance Name & $\begin{array}{l}\text { Alt. } \\
\text { (m) }\end{array}$ & $\begin{array}{l}\text { Ann. } \\
\text { Mean } \\
\text { Temp. } \\
\left({ }^{\circ} \mathrm{C}\right)\end{array}$ & $\begin{array}{l}\text { Ann. } \\
\text { Mean } \\
\text { Prec. } \\
(\mathrm{mm})\end{array}$ & $\begin{array}{l}\text { Ann. } \\
C M D \\
(\mathrm{~mm})\end{array}$ & & $\begin{array}{c}\text { Temp. } \\
\text { Annual } \\
\text { Change } \\
\left({ }^{\circ} \mathrm{C}\right)\end{array}$ & $\begin{array}{c}\text { Prec. } \\
\text { Annual } \\
\text { Change } \\
(\mathrm{mm})\end{array}$ & $\begin{array}{l}\text { Ann. } \\
d C M D \\
(\mathrm{~mm})\end{array}$ & $\begin{array}{l}\text { Proj. } \\
\text { Mean } \\
\text { Height } \\
\text { (m)*** }\end{array}$ \\
\hline 74 & A. alba & Milevsko, Klučenice CZ & 410 & 8.4 & 492 & 284 & 17.19 & 4.5 & 127 & 46 & 15.97 \\
\hline 81 & A. alba & Vyšší Brod, Vítkův Kámen CZ & 900 & 5.9 & 854 & 122 & 15.47 & 4.5 & 226 & -39 & 17.13 \\
\hline 109 & A. cephalonica & Centr. Peloponnese, Vytina GR & 1250 & 10.9 & 794 & 573 & 14.19 & 4.2 & -71 & 131 & 12.06 \\
\hline 130 & A. alba & Nasavrky, Podhura CZ & 370 & 8.2 & 487 & 253 & 16.89 & 4.5 & 123 & 44 & 15.94 \\
\hline $132^{*}$ & A. alba & Rilskije gory, Borovec BG & 1200 & 7.3 & 515 & 362 & 16.85 & 5.0 & 20 & 172 & 13.03 \\
\hline 136 & A. cephalonica & Peloponnese, Vytina GR & 1010 & 12.2 & 753 & 626 & 14.34 & 4.2 & -65 & 135 & 12.77 \\
\hline $137^{*}$ & A. borisii-regis & Mt. Pindos, Pertuli GR & 1200 & 9.6 & 727 & 503 & 14.59 & 4.8 & -31 & 162 & 11.26 \\
\hline $223^{*}$ & A. alba & Sanski Most BH & 1050 & 6.9 & 943 & 170 & 15.61 & 4.7 & 130 & 97 & 14.78 \\
\hline $228^{*}$ & A. alba & Regello, Vallombrosa IT & 1010 & 9.5 & 967 & 180 & 14.82 & 4.5 & 109 & 91 & 13.95 \\
\hline$S 2^{*}$ & A. alba & Banská Bystrica, Radvaň SK & 780 & 6.4 & 759 & 152 & 14.92 & 4.8 & 180 & 28 & 15.38 \\
\hline \multicolumn{3}{|c|}{ Data and current climate of the test site ${ }^{* *}$} & 395 & 8.1 & 570 & 213 & 15.49 & & & & \\
\hline
\end{tabular}

${ }^{*}$ Corrected locations; ${ }^{* *} \mathrm{CZ}$ met data (except CMD value of the test site; ${ }^{* *}$ Projected heights of Balkan fir species are estimated using the equation for silver fir. Source of climate data: ClimateEU v4.80. Projected heights are calculated for the age in the year 2015, for the sake of comparison. Current climate data are for all provenances the data of the Písek site (Table 3).

Separate Presentation of Height Responses to Temperature and Precipitation Changes in the Summer (Warmest) Quarter, Caused by Transfer of Populations to the Trials

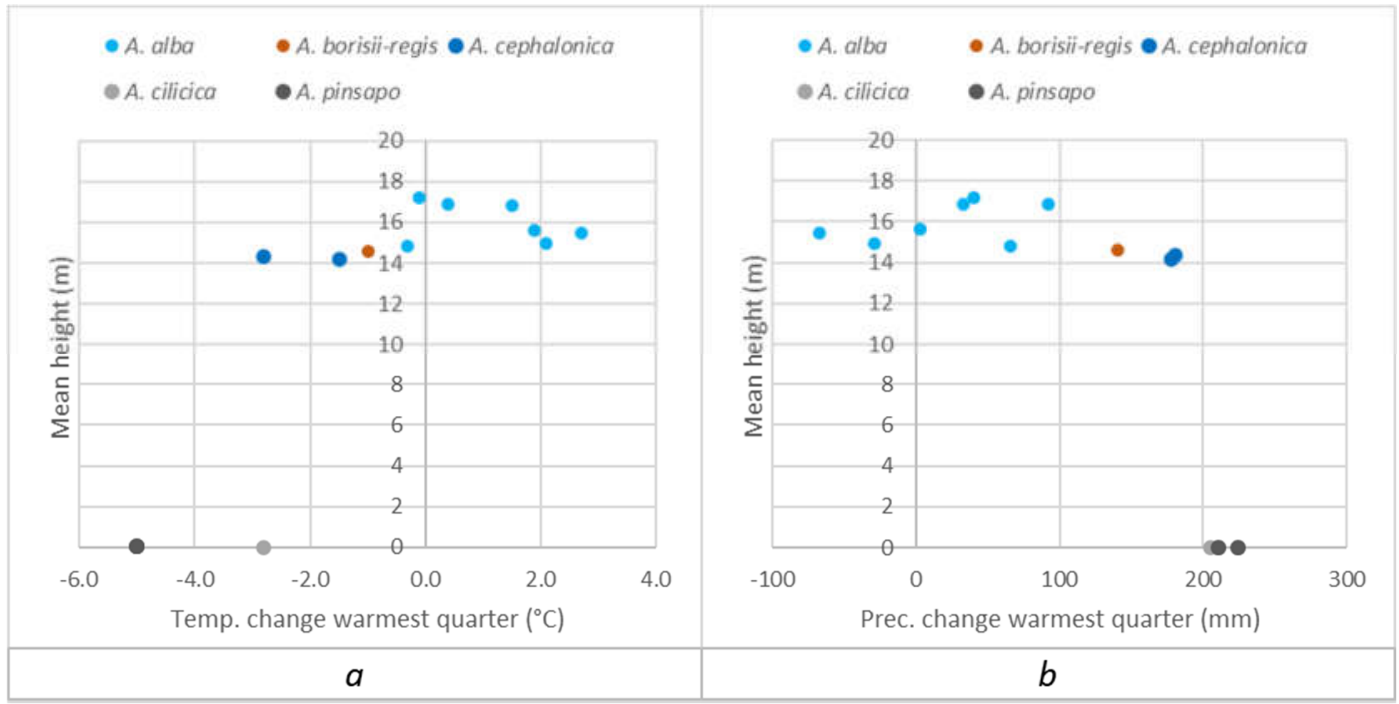

Figure A1. Mean summer temperature (a) and precipitation (b) change versus mean height of silver fir (blue), A. cephalonica (red) and $A$. borisii-regis (deep blue) provenances at the age of 40 years, in the trial 64, Písek. The Mediterranean provenances of $A$. cilicica and A. pinsapo (gray) suffered total mortality, depicted at 0 height. 


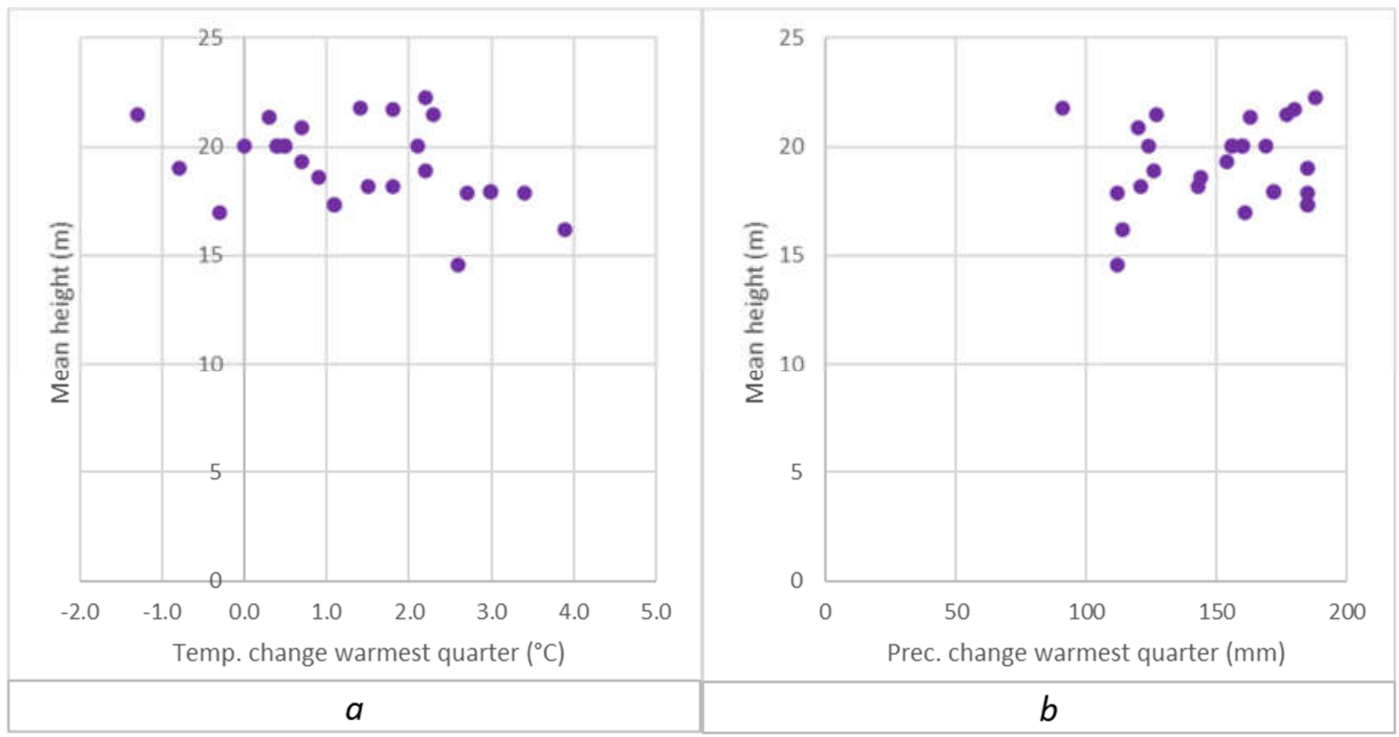

Figure A2. Mean summer temperature (a) and precipitation (b) change versus mean height of grand fir provenances at the age of 36 years, in the trial 213, Zbiroh. Note that nearly all populations were transferred into a warmer summer climate with higher rainfall.

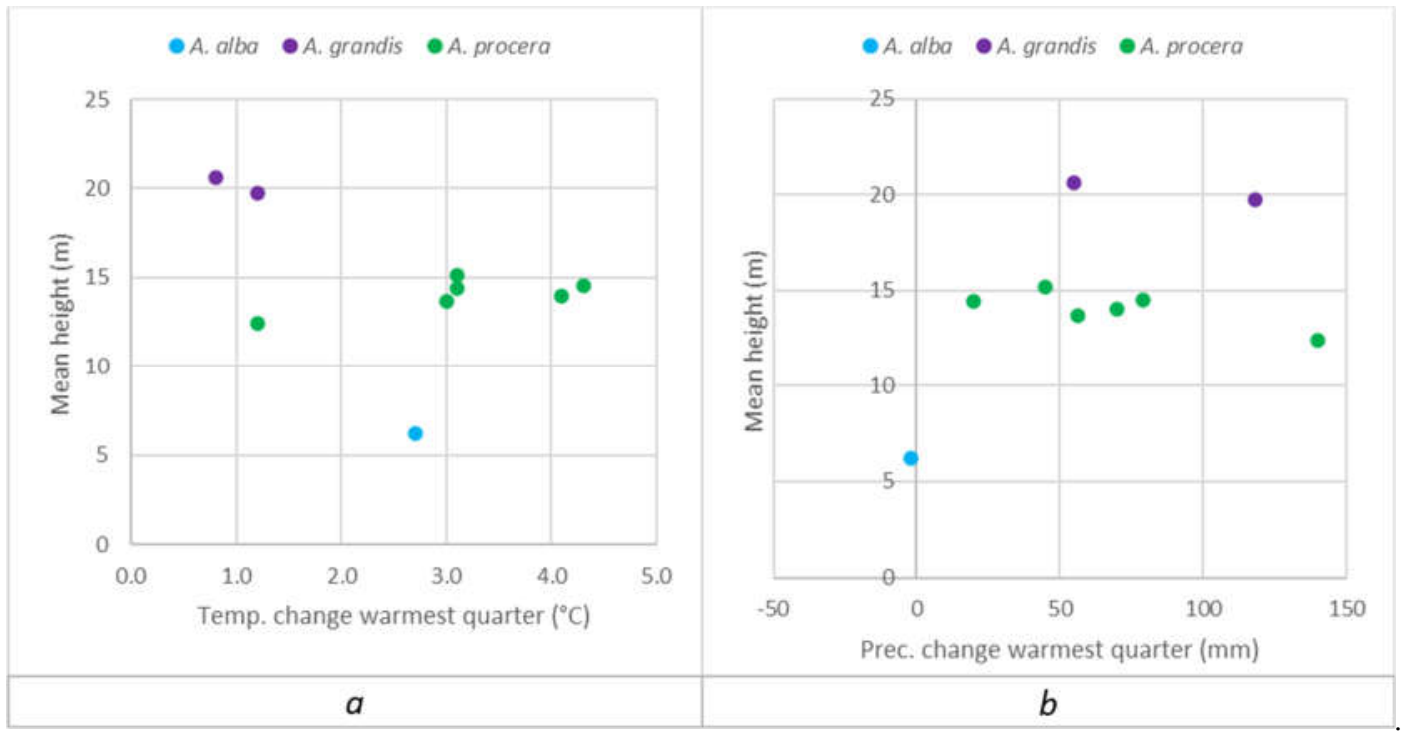

Figure A3. Mean summer temperature (a) and precipitation (b) change versus mean height of provenances of three species at the age of 32 years, in the trial 219, Dražičky. Note the differences between grand fir, noble fir and the autochthonous standard Adršpach from the Czech Sudeten Mts.

Matrices of Significance Calculated for the Three Provenance Tests, Based on Statistics in [20]

The Kruskal-Wallis one-way ANOVA results indicate significant differences of mean heights between pairs of populations. The populations are sorted by the average heights of groups in a quadrat (respectively, by geographic position in case of Zbiroh). Populations with top height are placed to the top left corner. As the height differences within the separated groups were found to be insignificant, the sequence of individual provenances within the group is not necessarily by their mean height. Filled circles indicate significant differences, colored fields signify differentiated groups. The quadrats of nonsignificantly different populations may overlap. 


\begin{tabular}{|c|c|c|c|c|c|c|c|c|c|c|}
\hline & 74 & 130 & 132 & 23 & 81 & 228 & 52 & 100 & 136 & 137 \\
\hline 74 & & 0 & 0 & $\bullet$ & $\bullet$ & $\bullet$ & $\bullet$ & $\bullet$ & $\bullet$ & $\bullet$ \\
\hline 130 & ○ & & 0 & 0 & 0 & $\bullet$ & • & • & $\bullet$ & $\bullet$ \\
\hline 132 & $\circ$ & 0 & & 0 & 0 & $\bullet$ & • & $\bullet$ & $\bullet$ & • \\
\hline 223 & • & 0 & 0 & & 0 & 0 & 0 & $\bullet$ & $\bullet$ & • \\
\hline 81 & $\bullet$ & 0 & 0 & 0 & & 0 & 0 & 0 & 0 & 0 \\
\hline 228 & $\bullet$ & $\bullet$ & $\bullet$ & 0 & 0 & & 0 & 0 & 0 & 0 \\
\hline 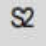 & $\bullet$ & $\bullet$ & $\bullet$ & 0 & 0 & 0 & & 0 & 0 & 0 \\
\hline 100 & $\bullet$ & $\bullet$ & $\bullet$ & $\bullet$ & 0 & 0 & 0 & & 0 & 0 \\
\hline 136 & $\bullet$ & $\bullet$ & $\bullet$ & $\bullet$ & 0 & 0 & 0 & 0 & & 0 \\
\hline 137 & $\bullet$ & $\bullet$ & $\bullet$ & $\bullet$ & $\circ$ & 0 & 0 & 0 & 0 & \\
\hline
\end{tabular}

Figure A4. Matrix of significance of population mean height differences of the trial Písek, sorted by the group average of mean heights (best in top left). 


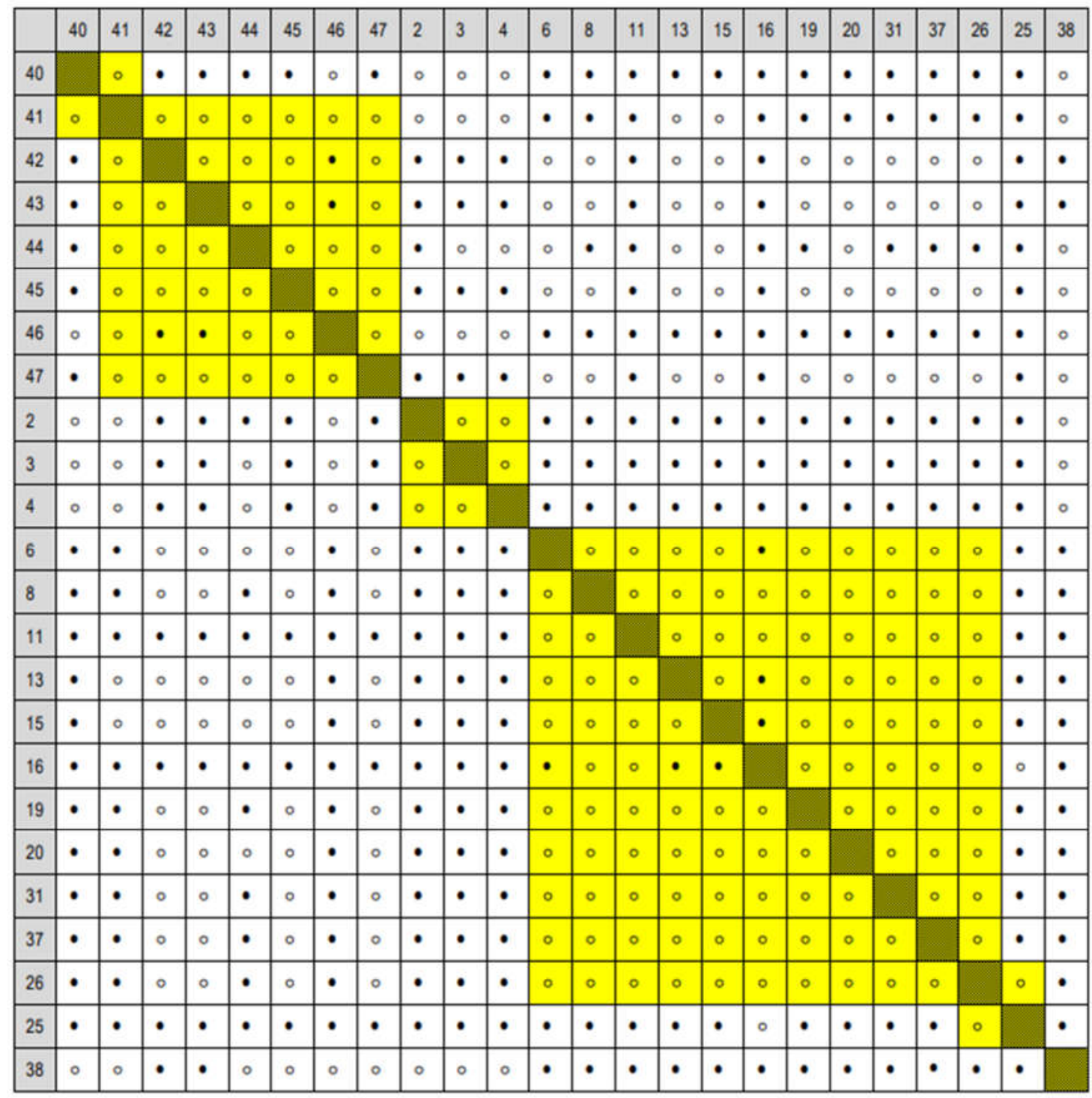

Figure A5. Matrix of significance of population mean height differences of the trial Zbiroh, sorted by their geographic position from NW to SE (the first three digits of the reg. numbers are omitted). 


\begin{tabular}{|c|c|c|c|c|c|c|c|c|c|}
\hline & 12001 & 12002 & 13011 & 13014 & 13018 & 1321 & 13006 & 13004 & $C O$ \\
\hline 12001 & & 0 & $\bullet$ & $\bullet$ & $\bullet$ & $\bullet$ & $\bullet$ & $\bullet$ & $\bullet$ \\
\hline 12006 & 0 & & $\bullet$ & $\bullet$ & $\bullet$ & $\bullet$ & $\bullet$ & $\bullet$ & $\bullet$ \\
\hline 13011 & $\bullet$ & $\bullet$ & & 0 & 0 & 0 & 0 & $\bullet$ & $\bullet$ \\
\hline 13014 & $\bullet$ & $\bullet$ & 0 & & 0 & 0 & 0 & $\bullet$ & $\bullet$ \\
\hline 13018 & $\bullet$ & $\bullet$ & 0 & 0 & & 0 & 0 & $\bullet$ & $\bullet$ \\
\hline 1301 & • & $\bullet$ & 0 & 0 & 0 & & 0 & 0 & $\bullet$ \\
\hline 13006 & $\bullet$ & $\bullet$ & 0 & 0 & 0 & 0 & & 0 & $\bullet$ \\
\hline 13004 & $\bullet$ & $\bullet$ & $\bullet$ & $\bullet$ & $\bullet$ & 0 & 0 & & $\bullet$ \\
\hline$c 0$ & $\bullet$ & $\bullet$ & $\bullet$ & $\bullet$ & $\bullet$ & $\bullet$ & $\bullet$ & $\bullet$ & \\
\hline
\end{tabular}

Figure A6. Matrix of significance of population mean height differences of the trial Dražičky, ordered by the group average of mean heights (best in top left).

Variance of Populations Sorted by the Sequence of Significance Statistics (The Sequence of Provenances follow the Respective Matrices of Significance)

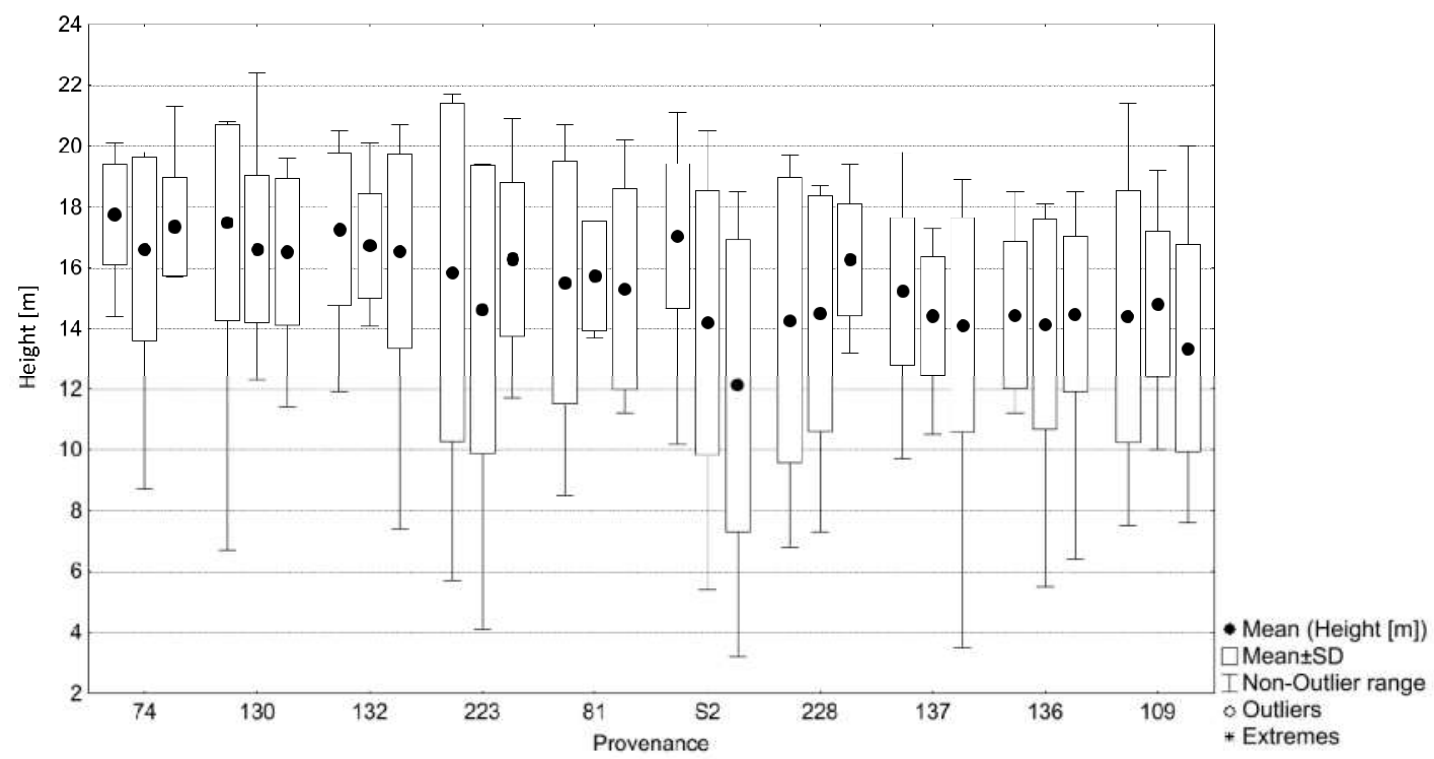

Figure A7. Box plot of height variation statistics by repetitions and by provenances in the trial Písek. The provenances are sorted by groups of mean heights (compare Figure A4). 


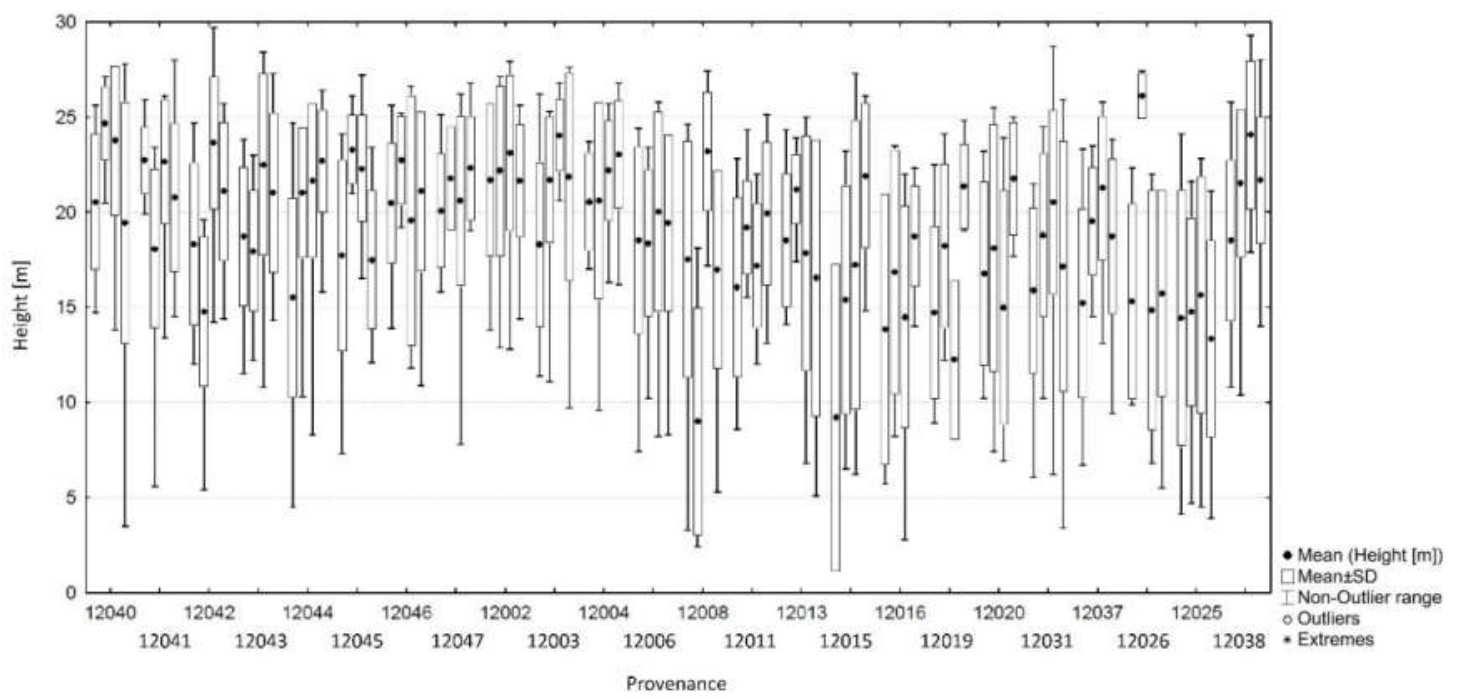

Figure A8. Box plot of height variation statistics by replications and by provenance in the trial Zbiroh. The provenances are sorted by geographic position (compare Figure A5).

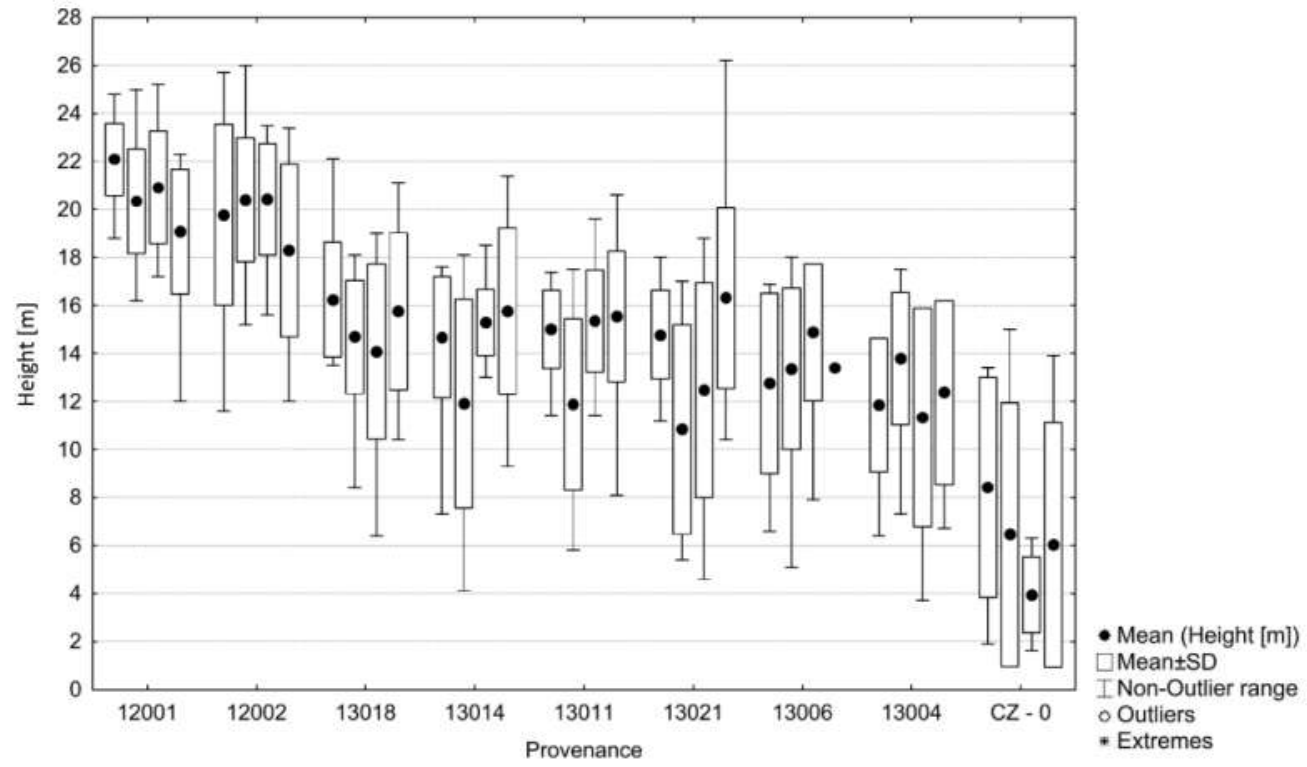

Figure A9. Box plot of height variation statistics by replications and by provenance in the trial Dražičky. The provenances are sorted by groups of mean heights (compare Figure A6).

\section{References}

1. Allen, C.D.; Breshears, D.D.; McDowell, N.G. On underestimation of global vulnerability to tree mortality and forest die-off from hotter drought in the Anthropocene. Ecosphere 2015, 6, 129, doi.10.1890/ES15-00203.1.

2. Mátyás, C. Forecasts needed for retreating forests (Opinion). Nat. Intern. Weekl. J. Sci. 2010, 464, 1271.

3. Mátyás, C.; Berki, I.; Bidló, A.; Csóka, G.; Czimber, K.; Führer, E.; Gálos, B.; Gribovszki, Z.; Illés, G.; Hirka, A.; et al. Sustainability of forest cover under climate change on the temperate-continental xeric limits. Forests 2018, 9, 489, doi:10.3390/f9080489.

4. Spinoni, J.; Barbosa, P.; Bucchignani, E.; Cassano, J.; Cavazos, T.; Christensen, J.H.; Dosio, A. Future global meteorological drought hotspots: A study based on CORDEX data. J. Climate. 2019, doi:10.1175/JCLI-D-19-0084.

5. Gálos, B.; Führer, E.; Czimber, K.; Gulyás, K.; Bidló, A.; Hänsler, A.; Jacob, D.; Mátyás, C. Climatic threats determining future adaptive forest management-A case study of Zala County. Idójárás 2015, 119, 425-441.

6. Czimber, K.; Gálos, B. A new decision support system to analyse the impacts of climate change on the Hungarian forestry and agricultural sectors. Scand. J. For. Res. 2016, 664-673, doi:10.1080/02827581.2016.1212088. 
7. Gazol, A.; Camarero, J.J.; Gutiérrez, E.; Popa, I.; Andreu-Hayles, L.; Motta, R.C.; Carrer, M. Distinct effects of climate warming on populations of silver fir (Abies alba) across Europe. J. Biogeogr. 2015, 42, 1150-1162, doi:10.1111/jbi.12512.

8. Matías, L.; Gonzalez-Díaz, P.; Quero, J.L.; Camarero, J.J.; Lloret, F.; Jump, A.S. Role of geographical provenance in the response of silver fir seedlings to experimental warming and drought. Tree Physiol. 2016, 36, 1236-1246, doi:10.1093/treephys/tpw049.

9. Brázdil, R.; Trnka, M. Sucho v českých zemích: Minulost, současnost, budoucnost. In Drought in the Czech Lands: Past, Present, Future, 1st ed.; Research Centre for Global Change, Academy of Science of the Czech Republic: Brno, Czech Republic; UNI Press: Turnov, Czech Republic, 2015. (In Czech)

10. Šindelář, J.; Frýdl, J. K problematice genetických změn v populacích lesních dřevin v důsledku narušování lesů škodlivými vlivy prostředí. Problems of genetic changes in forest tree populations due to disturbances by harmful environmental influences. Zpráoy Lesn. Výzk. 2008, 53, 116-119. (In Czech)

11. Lebourgeois, F.; Rathgeber, C.B.K.; Ulrich, E. Sensitivity of French temperate coniferous forests to climate variability and extreme events (Abies alba, Picea abies and Pinus sylvestris). J. Veget. Sci. 2010, 21, 364-376, doi:10.1111/j.1654-1103.2009.01148.x.

12. George, J.-P.; Grabner, M.; Campelo, F.; Karanitsch-Ackerl, S.; Mayer, K.; Klumpp, R.T.; Schüler, S. Intra-specific variation in growth and wood density traits under water-limited conditions: Long-term-, short-term-, and sudden responses of four conifer tree species. Sci. Total Environ. 2019, 660, 631-643, doi:10.1016/j.scitotenv.2018.12.478.

13. Vitasse, Y.; Bottero, A.; Rebetez, M.; Conedera, M.; Augustin, S.; Brang, P.; Tinner, W. What is the potential of silver fir to thrive under warmer and drier climate? Eur. J. Forest Res. 2019, doi:10.1007/s10342-019-01192-4.

14. Benito-Garzón, M.; Robson, T.M.; Hampe, A. $\Delta$ TraitSDM: Species distribution models that account for local adaptation and phenotypic plasticity. New Phytol. 2019, 222, 1757-1765, doi:10.1111/nph.15716.

15. Bouriaud, O.; Popa, I. Comparative dendroclimatic study of Scots pine, Norway spruce, and silver fir in the Vrancea Range, Eastern Carpathian Mountains. Trees 2008, 23, 95-106, doi:10.1007/s00468-008-0258-z.

16. Tinner, W.; Colombaroli, D.; Heiri, O.; Henne, P.D.; Steinacher. M.; Untenecker, J.; Conedera, M. The past ecology of Abies alba provides new perspectives on future responses of silver fir forests to global warming. Ecol. Monogr. 2013, 83, 419-439.

17. Zang, C.; Hartl-Meier, C.; Dittmar, C.; Rothe, A.; Menzel, A. Patterns of drought tolerance in major European temperate forest trees: Climatic drivers and levels of variability. Global Chang. Biol. 2014, 20, 3767-3779, doi:10.1111/gcb.12637.

18. Vitali, V.; Büntgen, U.; Bauhus, J. Silver fir and Douglas fir are more tolerant to extreme droughts than Norway spruce in southwestern Germany. Glob. Chang. Biol. 2017, 23, 5108-5119, doi.10.1111/gcb.13774.

19. Kapeller, S.; Schuiler, S.; Huber, G.; Božič, G.; Wohlgemuth, T.; Klumpp, R. Provenance Trials in Alpine Range-Review and Perspectives for Applications in Climate Change. In Management Strategies to Adapt Alpine Space Forests to Climate Change Risks; Cerbu, G., Ed.; IntechOpen: London, UK, 2013; ISBN 978-953-51-1194-8, doi:10.5772/56283.

20. Frýdl, J.; Dostál, J.; Beran, F.; Čáp, J.; Fulín, M.; Frampton, J.; Božič, G.; Mátyás, C. Exotic Abies Species in Czech Provenance Trials: Assessment after Four Decades. Acta Silv. Lign. Hung. 2018, 14, 1, 9-34, doi:10.2478/aslh-2018-0001.

21. Sáenz-Romero, C.; Mendoza-Maya, E.; Gómez-Pineda, E.; Blanco-García, A.; Endara-Agramont, A.R.; Lindig-Cisneros, R.; Vargas-Hernández, J.J. Recent evidence of Mexican temperate forest decline and the need for ex situ conservation, assisted migration, and translocation of species ensembles as adaptive management to face projected climatic change impacts in a megadiverse country. Can. J. For. Res. 2020, 50, 843-854, doi:10.1139/cjfr-2019-0329.

22. Booth, T.H. Assessing species climatic requirements beyond the realized niche: Some lessons mainly from tree species distribution modelling. Clim. Chang. 2017, 145, 259-271.

23. Mátyás, C.; Yeatman, C.W. Effect of geographical transfer on growth and survival of jack pine (Pinus banksiana Lamb.) populations. Silvae Genet. 1992, 41, 370-376.

24. Mátyás, C. Modelling climate-change effects with provenance test data. Tree Physiol. 1994, 14, 797-804, doi:10.1093/treephys/14.7-8-9.797.

25. Sagnard, F.; Barberot, C.; Fady, B. Structure of genetic diversity in Abies alba Mill. from southwestern Alps: Multivariate analysis of adaptive and non-adaptive traits for conservation in France. For. Ecol. Manag. 2002, 157, 175-189.

26. Latreille, A.C.; Pichot, C. Local-scale diversity and adaptation along elevational gradients assessed by reciprocal transplant experiments: Lack of local adaptation in silver fir populations. Ann. For. Sci. 2017, 74, 77, doi:10.1007/s13595-017-0673-7.

27. Mayer, H.; Reimoser, F.; Kral, F. Ergebnisse des Internationalen Tannenherkunftsversuches Wien 1967-1978. Morphologie und Wuchsverhalten der Provenienzen. Cbl. Ges. Forstw. 1982, 99, 169-191.

28. Ruetz, W.F.; Dimpflmeier, R.; Kleinschmit, J.; Svolba, J.; Weisgerber, H.; Rau, H.M. The IUFRO Abies procera provenance trial in the Federal Republic of Germany: Field results at age 9 and 10 years. In Proc. Jt. Meet. West. For. Genetics Assoc. and IUFRO W. P. S2.02-05, 06, 12 and 14; Weyerhaeuser Co.: Olympia, WA, USA, 1990.

29. Ruetz, W.; Stimm, B. Der Süddeutsche Weißtannen-Provenienzversuch: IV. Entwicklung der Herkünfte der Aussaat 1982 auf den Versuchsflächen in Bayern bis zum Alter von 12 Jahren. In Ergebnisse des 7. Weisstannen-Symposiums in Altensteig, Deutschland; Eder, W., Ed.; IUFR0-Verlag: Mainz, Germany, 1994; pp. 17-29.

30. Klumpp, R.T. Der Tannenprovenienzversuch "Knödelhütte Wien 1967": Ergebnisse im Alter 24. Mitt. Forsch. Anst. Waldökol. Forstw. RheinIand-Pfalz. 2002, 50/03, 44-49.

31. Gugerli, F.; Frank, A.; Rellstab, C.; Pluess, A.R.; Moser, B.; Ahrend, M.; Sperisen, C.; Wohlgemuth, T.; Heiri, C. Genetische Variation und lokale Anpassung bei Waldbaumarten im Zeichen des Klimawandels. (Genetic variation and local Adaptation in forest tree species under climate change.) In Wald im Klimawandel. Grundlagen für Adaptationsstrategien. (Forests in Climate 
Change. Basics of Adaptation Strategies.); Pluess, A.R., Augustin, S., Brang, P., Eds.; BAFU, WSL Birmensdorf, Haupt Verl.: Bern, Switzerland, 2016; pp. 93-118.

32. Frank, A.; Sperisen, C.; Howe, G.T.; Brang, P.; Walthert, L.; St. Clair, J.B.; Heiri, C. Distinct genecological patterns in seedlings of Norway spruce and silver fir from a mountainous landscape. Ecology 2017, 98, 211-227, doi:10.1002/ecy.1632.

33. Csilléry, K.; Buchmann, N.; Fady, B. Adaptation to drought is coupled with slow growth, but independent from phenology in marginal silver fir (Abies alba Mill.) populations. Evol. Appl. 2020, 13. doi:10.1111/eva.13029.

34. Hansen, J.K.; Larsen, J.B. European silver fir (Abies alba Mill.) provenances from Calabria, Southern Italy: 15-year results from Danish provenance field trials. Eur. J. For. Res. 2004, 123, 127-138.

35. George, J.P.; Schueler, S.; Karanitsch-Ackerl, S.; Mayer, K.; Klumpp, R.T.; Grabner, M. Inter- and intra-specific variation in drought sensitivity in Abies spec. and its relation to wood density and growth traits. Agric. For. Meteorol. 2015, 214-215, 430-443.

36. Bošel'a, M. Jedl'a biela: Perspektívna drevina v čase meniacej sa klímy? [Silver fir: A species with perspective in case if climate changes?] In Zachovanie druhovej rozmanitosti lesov Slovenska v čase globálnych environmentálnych zmien. [Conservation of species diversity of Slovakia's forests in times of global environmental change]; Mális, F., Ed.; Bulletin Správy, Forestry Faculty, TU Zvolen 2017; pp. 3-9. (in Slovak)

37. Csilléry, K.; Ovaskainen, O.; Sperisen, C.; Buchmann, N.; Widmer, A.; Gugerli, F. Adaptation to local climate in multi-trait space: Evidence from silver fir (Abies alba Mill.) populations across a heterogeneous environment. Heredity 2020, 124, 77-92.

38. Šindelář, J.; Beran, F. Comparison of some exotic species of Abies genus with chosen silver fir provenances on the plots of town Písek. Comm. Inst. For. Bohem. 2008, 24, 99-113.

39. Šindelár̆, J.; Beran, F. Exotic species of fir (Abies spec. div.) at the age of 30 years in the nature forest region No. 10-Středočeská pahorkatina (Central Bohemian Upland). Comm. Inst. For. Bohem. 2008, 24, 115-130.

40. Mátyás, C. Adaptive pattern of phenotypic plasticity and inherent growth reveal the potential for assisted transfer in sessile oak (Quercus petraea L.). For. Ecol. Manag. 2021, 482, 118832.

41. Nielsen, R. The Little Green Handbook; Publisher: Scribe Publications, London, 2006; ISBN 0312425813. Available online: http://home.iprimus.com.au/nielsens/ (accessed on Dec. 2, 2020).

42. Steffen, W.; Broadgate, W.; Deutsch, L.; Gaffney, O.; Ludwig, C. The Trajectory of the Anthropocene: The Great Acceleration. Anthr. Rev. 2015, 2, 81-98. Available online: http://hdl.handle.net/1885/66463 (accessed on Dec. 4, 2020).

43. Marchi, M.; Castellanos-acuña, D.; Hamann, A.; Wang, T.; Ray, D.; Menzel, A. ClimateEU, scale-free climate normals, historical time series, and future projections for Europe. Sci. Data 2020, 7, 428, doi:10.1038/s41597-020-00763-0.

44. Wang, T.; Hamann, A.; Spittlehouse, D.L.; Murdock, T.Q. ClimateWNA-high-resolution spatial climate data for western North America. J. Appl. Meteorol. Climatol. 2012, 51, 16-29, doi:10.1175/JAMC-D-11-043.1.

45. Hargreaves, G.H. Defining and using reference evapotranspiration. J. Irrigat. Drain. Eng. 1994, 120, 6, doi/:10.1061/(ASCE)07339437(1994)120:6(1132).

46. QC-Expert 3.1 TriloByte Statistical Software. TriloByte Ltd., Pardubice-Staré Hradiště, Czech Republic. Available online: http://www.trilobyte.cz/Nase-Produkty/QC-Expert.html

47. CEDA Archive. Climate Research Unit, UK, Time Series Version 3.23, High Resolution Gridded Data. 2018. Available online: http://catalogue.ceda.ac.uk/uuid/5dca9487dc614711a3a933e44a933ad3 (accessed on N. A.).

48. Alizoti, P.; Bastien, J.C.; Chakraborty, D.; Klisz, M.; Kroon, J.; Neophytou, C.; Schueler, S.; van Loo, M.; Westergren, M.; Konnert, M. and 21 contributors. Non-native forest tree species in Europe: The question of seed origin in afforestation. Forestry 2019. Available online: http://mc.manuscriptcentral.com/forest (accessed on Nov. 10, 2020).

49. Mátyás, C.; Bozic, G.; Gömöry, D.; Ivankovic, M.; Rasztovits, E. Juvenile growth response of European beech (Fagus sylvatica L.) to sudden change of climatic environment in SE European trials. iForest, J. Biogeosc. For. 2009, 2, $213-220$.

50. Konôpková, A.; Pšidová, E.; Kurjak, D.; Stojnić, S.; Petrík, C.P.; Fleischer, A.P.; Ditmarová, L. Photosynthetic performance of silver fir (Abies alba) of different origins under suboptimal growing conditions. Funct. Plant. Biol. 2020, 47, doi:10.1071/FP20040.

51. Mosca, E.; Cruz, F.; Gómez-Garrido, J.; Bianco, L.; Rellstab, C.; Brodbeck, S.; Neale, D.B. A Reference Genome Sequence for the European Silver Fir (Abies alba Mill.): A Community-Generated Genomic Resource. G3 Genes Genomes Genetics 2019, 9, 2039_ 2049.

52. Fulín, M.; Remeš, J.; Tauchman, P. Růst a produkce jedle obrovské (Abies grandis Lindl.) ve srovnání s jinými jehličnany. Growth and production of grand fir (Abies grandis Lindl.) compared with other conifer species. Zprávy lesn. výzk. 2013, 58, 186-192. (in Czech)

53. Roschanski, A.M.; Csilléry, K.; Liepelt, S.; Oddou-Muratorio, S.; Ziegenhagen, B.; Huard, F.; Fady, B. Evidence of divergent selection for drought and cold tolerance at landscape and local scales in Abies alba Mill. in the French Mediterranean Alps. Mol. Ecol. 2016, 25, 776-794, doi:10.1111/mec.13516.

54. Čáp, J.; Novotný, P.; Frýdl, J. Vyhodnocení provenienční výzkumné plochy s jedlí bělokorou (Abies alba Mill.) č. 57-Lesy Jíloviště, Cukrák ve věku 35 let. Evaluation of a provenance research trial with silver fir at the age of 35 years. Zprávy Lesn. Výzk. 2009, 54, 33-43. (In Czech)

55. Rehfeldt, G.E.; Leites, L.P.; Joyce, D.G.; Weiskittel, A.R. Role of population genetics in guiding ecological responses to climate. Glob. Chang. Biol. 2018, 24, 858-868, doi:10.1111/gcb.13883.

56. Rehfeldt, G.E.; Warwell, M.V.; Monserud, R.A. Species, climatypes, climate change and forest health: A conversion of science to practice for inland northwest (USA) forests. Forests 2020, 11, 1237, doi:10.3390/f11121237. 
57. Mihai, G.; Alexandru, A.M.; Stoica, E.; Birsan, M.V. Intraspecific growth response to drought of Abies alba in the Southeastern Carpathians. Forests 2021, 12, 387, doi:10.3390/f12040387.

58. Wilczyński, S.; Kulej, M. The growth of seven Abies grandis provenances in the climatic conditions of the Polish Carpathian Mountains. Dendrobiology 2019, 81, 1-13.

59. Grady, K.C.; Kolb, T.E.; Ikeda, D.H.; Whitham, T.G. A bridge too far: Cold and pathogen constraints to assisted migration of riparian forests. Restor. Ecol. 2015, 23, 811-820. Available online: https://onlinelibrary.wiley.com/doi/abs/10.1111/rec.12245 (accessed on Dec. 5, 2020).

60. Adams, H.D.; Barron-Gafford, G.A.; Minor, R.L.; Gardea, A.A.; Bentley, L.P.; Law, D.J.; Huxman, T.E. Temperature response surfaces for mortality risk of tree species with future drought. Environ. Res. Lett. 2017, 12, 115014.

61. Berki, I.; Rasztovits, E.; Móricz, N.; Kolozs, L. The role of tree mortality in vitality assessment of sessile oak forests. South-East Eur. For. 2016, 7, 91-97, doi:10.15177/seefor.16-14.

62. Střelcová, K. Stres suchom a lesné porasty. [Drought stress and forest trees]. In Zachovanie druhovej rozmanitosti lesov Slovenska v čase globálnych environmentálnych zmien. [Conservation of species diversity of Slovakia's forests in times of global environmental change]; Mális, F., Ed.; Bulletin Správy, Forestry Faculty, TU Zvolen 2017; pp. 59-71. (in Slovak) 